\title{
Exploring wild edible flowers as a source of bioactive compounds: New perspectives in horticulture
}

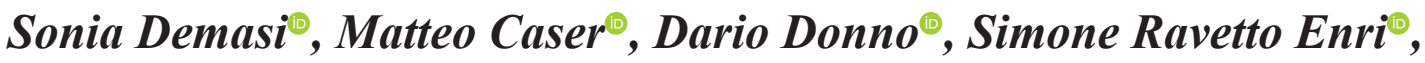 \\ Michele Lonati ${ }^{\oplus}$, Valentina Scariot* ${ }^{\oplus}$
}

Department of Agricultural, Forest and Food Sciences, University of Turin, Largo Paolo Braccini 2, 10095, Grugliasco (TO), Italy

\begin{abstract}
The increasing interest in healthy and natural foods has raised the attention towards uncommon or unexplored ingredients, such as edible flowers. These products are proven to be a rich source of bioactive compounds, for example, vitamins or polyphenols that play an important role in health promotion and disease prevention. However, plant species with edible flowers are numerous and most of them still need to be studied with this aim. The high species richness of North-Western Italy provides interesting perspectives in the use of wild edible flowers, which are currently underutilized, but can be a valuable food source or food supplement for healthy diets. In this framework, the phytochemical composition of 22 wild edible flowers was analysed and compared with that of four cultivated species (Borago officinalis L., Calendula officinalis L., Tagetes patula L. and Tropaeolum majus L.) to evaluate their potentiality as sources of bioactive compounds. The total polyphenol content (TPC) and antioxidant activity of the fresh flowers were assessed, together with their phenolic profiles and vitamin $\mathrm{C}$ content, through spectrophotometric and chromatographic analyses. The evaluated parameters varied widely among species, with Paeonia officinalis L. and Rosa pendulina L. showing the highest values of polyphenols (1,930 mg gallic acid equivalents (GAE) $\cdot 100 \mathrm{~g}^{-1}$ and $1,774 \mathrm{mg} \mathrm{GAE} \cdot 100 \mathrm{~g}^{-1}$, respectively), followed by Rosa canina L. (1,397 $\left.\mathrm{mg} \mathrm{GAE} \cdot 100 \mathrm{~g}^{-1}\right)$ and Geranium sylvaticum L. (1,268 mg GAE $\left.\cdot 100 \mathrm{~g}^{-1}\right)$. The same species also showed the highest antioxidant activity, measured with three different assays [ferric reducing antioxidant power (FRAP), 2,2-diphenyl-1-picrylhydrazyl (DPPH) and 2,2'-azino-bis-3-ethylbenzthiazoline-6-sulfonic acid (ABTS)]. The phenolic profile differed among the studied species, with Dianthus pavonius Tausch and $R$. pendulina having the highest sum of detected polyphenols $\left(2,522 \mathrm{mg} \cdot 100 \mathrm{~g}^{-1}\right.$ and 2,366 mg $100 \mathrm{~g}^{-1}$, respectively). Vitamin $\mathrm{C}$ was identified in all but two flowers (Allium ursinum L. and B. officinalis) and Primula veris L. had the highest amount $\left(45 \mathrm{mg} \cdot 100 \mathrm{~g}^{-1}\right)$. The study showed that wild edible flowers outperformed the cultivated species, except for T. majus, providing new insights for the use of wild edible flowers as sources of bioactive compounds.
\end{abstract}

Keywords: antioxidant activity, edible flowers, functional food, polyphenols, vitamin C

\section{INTRODUCTION}

The number of plant species considered edible in the world is about 30,000; however, very few of them are used to fulfil human food requirements (Shaheen et al., 2017). To this aim, the rich biodiversity and abundance of wild edible plants represent a precious resource still underutilized, and that can be used as food sources (Shaheen et al., 2017; Ceccanti et al., 2018;
Brito et al., 2021). In this framework, there are numerous plant species with edible flowers and studies ongoing to explore their potential in the human diet as food, supplements or additives (Loizzo et al., 2016; Fernandes et al., 2017; Mulík and Ozuna, 2020). Eating flowers is a legacy of many cultures that have been using flowers in their food traditions during centuries, but nowadays

*Corresponding author.

e-mail: valentina.scariot@unito.it (Valentina Scariot). 
edible flowers can also represent a source of nutrients and phytochemicals with health benefits. Despite this, only a small portion of species has been explored to date with this aim, such as Centaurea cyanus L., Hibiscus rosa-sinensis L., Calendula officinalis or Rosa spp. (Ceccanti et al., 2018; Pires et al., 2019; Takahashi et al., 2020). The legislation is currently lacking, as reported by Fernandes et al. (2017), since no international body (e.g. European Food Safety Authority - EFSA, Food and Drugs Administration - FDA, United Nations Food and Agriculture Organization-FAO) has released an official list of edible flowers to-date. Thus, the use, production and consumption must be carefully performed, especially when considering wild or underutilized plants, which need proper characterization of the species (Fernandes et al., 2017; Takahashi et al., 2020). Moreover, their eventual toxicity should be investigated, as well as the possibility that some flowers may be considered novel food according to legislation (e.g. European Regulation EU 2015/2283) (Egebjerg et al., 2018; Zhao et al., 2019).

The positive health effects of edible flowers are ascribed to their chemical composition, which are rich in phytochemicals with bioactive properties, such as vitamins (Fernandes et al., 2017; Scariot et al., 2018; Pires et al., 2019; Zhao et al., 2019; Mulík and Ozuna, 2020; Takahashi et al., 2020; Zheng et al., 2021). Vitamin $\mathrm{C}$ is a strong antioxidant that scavenges radicals, thus neutralizing oxidative stress and plays an important role in human metabolism, representing a fundamental supplement in the diet (Fascella et al., 2019; Caritá et al., 2020). Interesting results on the vitamin $C$ content in flowers have been recorded in plants of Zingiberaceae (Rachkeeree et al., 2018), Tropaeolum majus L. (Lim, 2014a) and cultivars of Paeonia lactiflora Pall. (Weixing et al., 2017). An increased number of studies have focused on polyphenols in flower extracts (Chensom et al., 2019; Kalemba-Drożdż and Cierniak, 2019; Moliner et al., 2019; Pires et al., 2019; Demasi et al., 2020; Montoro et al., 2020), a wide group of non-nutritional plant secondary metabolites that possess several beneficial properties and exert a strong antioxidant activity, scavenging reactive oxygen species (Del Rio et al., 2013; Durazzo et al., 2019). Considering the health benefits provided by polyphenols and antioxidants, increasing the knowledge of their content in unconventional matrixes can be a new challenge (D'Angiolillo et al., 2018; Durazzo et al., 2019), despite the content of single compounds often being in traces or lower than $1 \mathrm{mg} \cdot 100 \mathrm{~g}^{-1}$ of fresh weight $(\mathrm{FW})$, whatever the food considered (Pérez-Jiménez et al., 2010). This issue is of particular interest considering the edible flowers market, which is constantly increasing (Fernandes et al., 2020).

Polyphenols in foodstuffs are frequently evaluated as a whole group with colorimetric assays; however, the individual quantification of phenolic compounds is essential to understand the bioactivity potential and properties of food (Fernandes et al., 2017; PérezJiménez et al., 2010; Skrajda-Brdak et al., 2020), especially when studying unexplored or underutilized edible flowers. So far, wide variability in terms of total polyphenols and antioxidant activity has been recorded in edible flowers from Asian countries, where flowers are commonly consumed as food or medicine, for example, Bougainvillea glabra Choisy, Chrysanthemum spp., Hibiscus sabdariffa L., Nelumbo nucifera Gaertn., Osmanthus fragrans Lour, Paeonia spp., Rosa spp., Tagetes erecta L. (Wong et al., 2006; Kaisoon et al., 2012; Li et al., 2014; Xiong et al., 2014; Zeng et al., 2014; Lu et al., 2016; Zheng et al., 2018). Similarly, interesting results derived from European studies, focused on Borago officinalis L., C. officinalis L., Tagetes spp., Tropaeolum majus L., Rosa spp. and related cultivars, the most studied and produced edible flowers, used as garnishment or ingredients in salads and other dishes (Rop et al., 2012; Fernandes et al., 2017, 2020; Pires et al., 2019).

The high species richness of European biogeographic regions gives interesting perspectives in the use of wild edible flowers as human foodstuff. Particularly, North-Western Italy, characterized by a wide variety of habitats and vegetation communities, harbours a total of 4,020 taxa (Bartolucci et al., 2018).

In this study, we explored flowers from wild plants that grow spontaneously in self-maintaining populations in semi-natural habitats of North-Western Italy. A total of 26 species (including 22 wild and four commonly cultivated species) were analysed to evaluate their potential as sources of bioactive compounds, through the assessment of total polyphenol content (TPC), antioxidant activity, phenolic profiles and vitamin $\mathrm{C}$ content.

\section{MATERIALS AND METHODS}

\section{Plant material}

An extended area in North-Western Italy was explored (including Aosta Valley and Piedmont administrative regions), collecting flowers from 22 wild species (Table 1). Wild species were selected to explore all altitudinal belts in the studied area, including plain, colline, montane and alpine belts, and to investigate many vegetation communities. Aiming at this, each species was associated with the corresponding phytosociological optimum (at class level, according to Aeschimann et al., 2004), which were then pooled in eight different vegetation communities characterized by homogeneous ecological features: (i) nutrientrich grasslands (including Molinio-Arrhenatheretea phytosociological class), (ii) nutrient-poor grasslands (Juncetea trifidi class), (iii) dry grasslands (FestucoBrometea class), (iv) edges (Mulgedio-Aconitetea and Trifolio-Geranietea sanguinei classes), (v) ruderal communities (Stellarietea mediae and Artemisietea vulgaris classes), (vi) shrublands (Crataego-Prunetea class), (vii) wetlands (Phragmito-Magnocaricetea class) and (viii) woodlands (Carpino-Fagetea sylvaticae, 
Robinietea, and Roso pendulinae-Pinetea mugo classes). The month and site of sampling have been recorded for each species, as well as the soil and bedrock type of the sampling location. Besides, four commonly known and cultivated edible species were sampled in the nursery F.1li Gramaglia $\left(45^{\circ} 05^{\prime} 22.4^{\prime \prime} \mathrm{N}, 7^{\circ} 34^{\prime} 26.4^{\prime \prime} \mathrm{E}, 302\right.$ m.a.s.1., Collegno - TO, Italy). An amount of circa $100 \mathrm{~g}$ of flowers were collected per species in spring and summer 2017 at the optimal phenological stage (i.e. at full flowering), placed in sealed polyethylene bags, immediately stored at $4^{\circ} \mathrm{C}$ in a portable refrigerator and transported to the laboratory for analyses. Species nomenclature followed Pignatti et al. (2017). The plant list was checked with the available literature to consider mostly species with documented use by human society, as either food or medical stuff (Table 1), and their eventual presence in the Novel food catalogue of the European Commission was checked (https://ec.europa.eu/food/safety/novel_ food/catalogue_en).

\section{Extract preparation}

Fresh flower sample was grinded in a mortar using liquid nitrogen and then stored at $-80^{\circ} \mathrm{C}$ until the preparation of the extracts that was performed with ultrasoundassisted extraction, a high reproducible, efficient, simple, time- and solvent-saving methodology. The solid-liquid extraction using organic solvents and water mixture is among the most common methodologies to extract polyphenols (Pires et al., 2019; Takahashi et al., 2020); thus flower powder (1 g) was extracted with $50 \mathrm{~mL}$ of a water:methanol solution (1:1) at room temperature with an ultrasound extractor (Sarl Reus, Drap, France) at $23 \mathrm{kHz}$ for $15 \mathrm{~min}$ (Demasi et al., 2020). First, the solution was filtered with one layer of filter paper (Whatman No. 1, Maidstone, UK) and afterwards using a $0.45 \mu \mathrm{m}$ PVDF syringe filter (CPS Analitica, Milano, Italy). The extracts were stored at $-20^{\circ} \mathrm{C}$ until the performance of colorimetric and chromatographic analyses.

\section{TPC and antioxidant activity}

The TPC in flower extracts and the evaluation of their antioxidant activity were performed using colorimetric methods, reading the absorbance with the spectrophotometer Cary $60 \mathrm{UV}-\mathrm{Vis}$ (Agilent, Santa Clara, CA, USA). In particular, the TPC was analysed using the Folin-Ciocalteu method (Slinkard and Singleton, 1977; Sánchez-Rangel et al., 2013; Demasi et al., 2020). An amount of $200 \mu \mathrm{L}$ of flower extract were mixed with $1,000 \mu \mathrm{L}$ of diluted (1:10) FolinCiocalteu reagent. The samples were left in the dark at room temperature for $10 \mathrm{~min}$, then adding $800 \mu \mathrm{L}$ of $\mathrm{Na}_{2} \mathrm{CO}_{3}(7.5 \%)$. After $30 \mathrm{~min}$ in the dark at room temperature, absorbance was read at $765 \mathrm{~nm}$, expressing results as $\mathrm{mg}$ of gallic acid equivalents (GAE) per $100 \mathrm{~g}$ of FW (mg GAE $\cdot 100 \mathrm{~g}^{-1}$ ). The antioxidant activity was evaluated through three different assays: the ferric reducing antioxidant power (FRAP) method
(Benzie and Strain, 1998; Demasi et al., 2020), the 2,2-diphenyl-1-picrylhydrazyl (DPPH) assay (Wong et al., 2006) and the 2,2'-azino-bis-3-ethylbenzthiazoline6-sulfonic acid (ABTS) assay (Tawaha et al., 2007; Dudonné et al., 2009). In the FRAP method, $30 \mu \mathrm{L}$ of flower extract were mixed with $90 \mu \mathrm{L}$ of deionized water and $900 \mu \mathrm{L}$ of FRAP reagent. This was constituted of a buffer solution at $\mathrm{pH} 3.6\left(\mathrm{C}_{2} \mathrm{H}_{3} \mathrm{NaO}_{2}+\mathrm{C}_{2} \mathrm{H}_{4} \mathrm{O}_{2}\right.$ in water), 2,4,6-tripyridyltriazine (TPTZ, $10 \mathrm{mM}$ in $\mathrm{HCl} 40 \mathrm{mM}$ ) and $\mathrm{FeCl}_{3} \cdot 6 \mathrm{H}_{2} \mathrm{O}(20 \mathrm{mM})$. The samples were placed at $37^{\circ} \mathrm{C}$ for $30 \mathrm{~min}$ and absorbance was read at $595 \mathrm{~nm}$. The results were expressed as mill moles of ferrous iron $\left(\mathrm{Fe}^{2+}\right)$ equivalents per kilogram of $\mathrm{FW}$ (mmol $\mathrm{Fe}^{2+} \cdot \mathrm{kg}^{-1}$ ). In the DPPH assay, $40 \mu \mathrm{L}$ of flower extract was mixed with $3 \mathrm{~mL}^{-}$of $\mathrm{DPH}^{-}$radical solution. The samples were left in the dark at room temperature for $30 \mathrm{~min}$ and absorbance was read at $515 \mathrm{~nm}$. In the ABTS assays, $30 \mu \mathrm{L}$ of flower extract was mixed with $2 \mathrm{~mL}$ of ABTS' radical solution. The samples were left in the dark at room temperature for $10 \mathrm{~min}$ and absorbance was read at $734 \mathrm{~nm}$. Both DPPH and ABTS results were expressed as micro moles of Trolox Equivalents (TE) per $1 \mathrm{~g}$ of $\mathrm{FW}\left(\mu \mathrm{mol} \mathrm{TE} \cdot \mathrm{g}^{-1}\right)$.

\section{Phenolic profile and vitamin $C$}

The bioactive compounds present in the extracts of edible flowers were determined using High-Performance Liquid Chromatography (HPLC) with Diode Array Detection (DAD) (Agilent 1200, Agilent Technologies, Santa Clara, CA, USA). The separation of compounds was obtained with a Kinetex C18 column $(4.6 \times 150 \mathrm{~mm}$, $5 \mu \mathrm{m}$, Phenomenex, Torrance, CA, USA) and different mobile phases, according to previous validated methodology (Table 2; Caser et al., 2019; Donno et al., 2019). The identification of compounds was made by comparison with retention times and UV spectra of analytical standards and the quantification was achieved using calibration curves at the same chromatographic conditions. The following bioactive compounds were determined: phenolic acids (cinnamic acids: caffeic, chlorogenic, coumaric and ferulic acid; benzoic acids: ellagic and gallic acid); flavonols (hyperoside, isoquercitrin, quercetin, quercitrin and rutin); flavanols (catechin and epicatechin) and vitamin C. The results are expressed as $\mathrm{mg} \cdot 100 \mathrm{~g}^{-1}$ of fresh flower.

\section{Statistical analyses}

Raw data of TPC, FRAP, DPPH, and ABTS, were transformed in standard scores and averaged to obtain the Relative Antioxidant Capacity Index (RACI) (Sun and Tanumihardjo, 2007). Then, mean differences between species concerning dry matter content, spectrophotometric data (TPC, FRAP, DPPH, ABTS, RACI) and chromatographic data (class of compounds and single compounds) were analysed using generalized linear models (GLMs) with Gaussian or gamma distribution according to the distribution of data. Tukey's post hoc-test with Bonferroni's adjustment was used to 


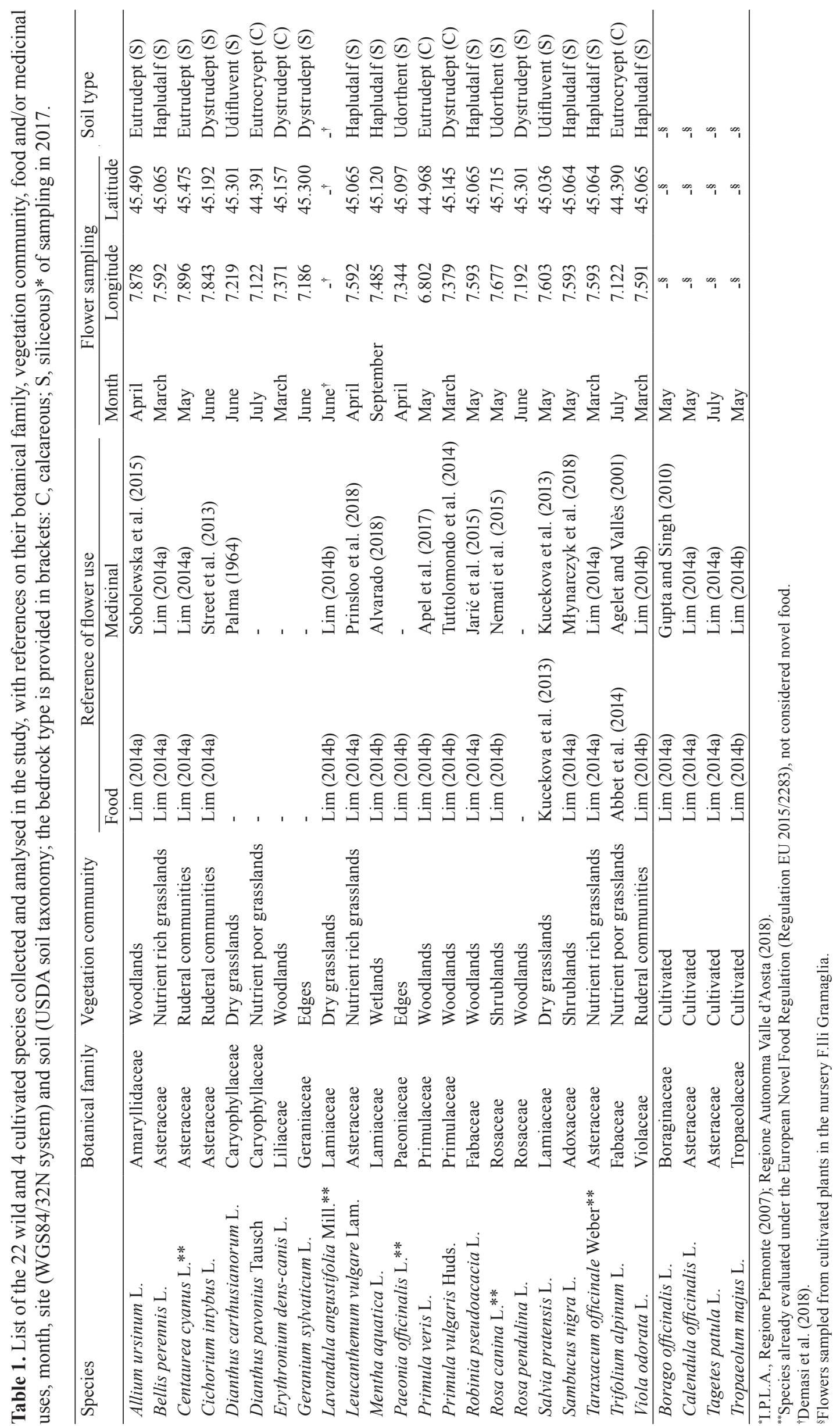


Table 2. Mobile phases, elution conditions and wavelength used to detect the five classes of compounds with HPLC analysis.

\begin{tabular}{|c|c|c|c|}
\hline Class of compounds & Mobile phase & Elution conditions & Wavelength (nm) \\
\hline $\begin{array}{l}\text { Cinnamic acids and } \\
\text { flavonols }\end{array}$ & $\begin{array}{l}\text { A: } 10 \mathrm{mM} \mathrm{KH}_{2} \mathrm{PO}_{4} / \mathrm{H}_{3} \mathrm{PO}_{4}, \mathrm{pH}=2.8 \\
\text { B: } \mathrm{CH}_{3} \mathrm{CN}\end{array}$ & $\begin{array}{l}5 \% \mathrm{~B} \text { to } 21 \% \mathrm{~B} \text { in } 17 \mathrm{~min}+21 \% \mathrm{~B} \text { in } 3 \mathrm{~min} \\
\text { ( } 2 \text { min conditioning time); flow: } 1.5 \mathrm{~mL} \mathrm{~min}{ }^{-1}\end{array}$ & 330 \\
\hline $\begin{array}{l}\text { Benzoic acids and } \\
\text { flavanols }\end{array}$ & $\begin{array}{l}\mathrm{A}: \mathrm{H}_{2} \mathrm{O} / \mathrm{CH}_{3} \mathrm{OH} / \mathrm{HCOOH} \\
(5: 95: 0.1 \mathrm{v} / \mathrm{v} / \mathrm{v}), \mathrm{pH}=2.5 \\
\mathrm{~B}: \mathrm{CH}_{3} \mathrm{OH} / \mathrm{HCOOH}(100: 0.1 \mathrm{v} / \mathrm{v})\end{array}$ & $\begin{array}{l}3 \% \mathrm{~B} \text { to } 85 \% \mathrm{~B} \text { in } 22 \mathrm{~min}+85 \% \mathrm{~B} \text { in } 1 \mathrm{~min} \\
\text { ( } 2 \text { min conditioning time); flow: } 0.6 \mathrm{~mL} \mathrm{~min}\end{array}$ & 280 \\
\hline Vitamin C & $\begin{array}{l}\text { A: } 5 \mathrm{mM} \mathrm{C}_{16} \mathrm{H}_{33} \mathrm{~N}\left(\mathrm{CH}_{3}\right)_{3} \mathrm{Br} / 50 \mathrm{mM} \\
\mathrm{KH}_{2} \mathrm{PO}_{4}, \mathrm{pH}=2.5 \\
\text { B: } \mathrm{CH}_{3} \mathrm{OH}\end{array}$ & 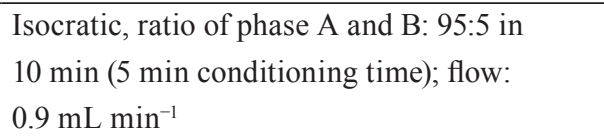 & 261,348 \\
\hline
\end{tabular}

HPLC, High-Performance Liquid Chromatography.

identify homogeneous groups of means when $p<0.05$ (R 3.6.2, R Foundation for Statistical Computing, Vienna, AT). Nonparametric Kruskal-Wallis test by stepwise comparison was performed on RACI data to avoid GLM misfunctioning due to the presence of non-positive values. Spearman's correlation analysis was used on TPC, FRAP, DPPH, ABTS, and phenolic profiles to evaluate the relationships between variables (SPSS, version 25.0, SPSS Inc., Chicago, Illinois, USA). Finally, the species were grouped according (i) to their TPC and antioxidant capacity and (ii) to their polyphenolic profiles and vitamin $\mathrm{C}$ content performing two hierarchical cluster analyses, respectively, using Euclidean distance measure and UPGMA linkage method (Past 3.11; Hammer et al., 2001).

\section{RESULTS AND DISCUSSION}

\section{TPC and antioxidant activity}

The flowers of the selected species showed highly significant differences in each of the recorded parameters (Table 3), including the content of dry matter, which ranged from $8.9 \%$ in T. majus to $31.2 \%$ in L. angustifolia. These results are in accordance with Fernandes et al. (2017) and Pires et al. (2019), who reported that water is the main constituent of edible flowers, accounting for $70-95 \%$ of the composition. Flowers were analysed fresh as they are mainly consumed fresh and since foods better retain their bioactive compounds when are minimally processed (Takahashi et al., 2020). Therefore, the results were expressed on an FW basis.

The highest amounts of TPC (Table 3) were detected in $P$. officinalis $\left(1,930.5 \mathrm{mg}\right.$ GAE $\left.\cdot 100 \mathrm{~g}^{-1}\right)$ and $R$. pendulina $\left(1,773.7 \mathrm{mg} \mathrm{GAE} \cdot 100 \mathrm{~g}^{-1}\right)$, with $R$. canina and $G$. sylvaticum also showing very high contents $(1,396.6$ and $1,267.8 \mathrm{mg} \mathrm{GAE} \cdot 100 \mathrm{~g}^{-1}$, respectively). The lowest TPC values were found in T. officinale, B. officinalis, $A$. ursinum and $C$. officinalis $(159.4,163.4,184.4,189.6 \mathrm{mg}$ GAE $\cdot 100 \mathrm{~g}^{-1}$, respectively). The TPC range recorded in this study is in line with those obtained from other reports on fresh edible flowers (Li et al., 2014; Petrova et al., 2016; Fernandes et al., 2017; Pires et al., 2019), whereas it is sensibly higher than values recorded in fresh rocket, basil, and Swiss chard microgreens (16-33 mg
GAE $\cdot 100 \mathrm{~g}^{-1}$ of FW, Bulgari et al., 2017). Comparing the literature, our data on fresh flowers of B. officinalis, $C$. cyanus and $S$. nigra are lower than in previous studies (Rop et al., 2012; Grzeszczuk et al., 2016; Młynarczyk et al., 2018), while data on C. officinalis, T. patula and $T$. majus are comparable (Garzón and Wrolstad, 2009; Rop et al., 2012; Lim, 2014a, 2014b). Interestingly, Rosa spp. and Paeonia spp. have already been reported to own very high values of TPC among several edible flowers (Kumar et al., 2009; Fan et al., 2012; Li et al., 2014; Xiong et al., 2014), confirming our findings.

Despite showing slight differences in antioxidant activity ranking, depending on the assay used (Table 3), the results showed that $P$. officinalis had always the highest activity (303.8 mmol $\mathrm{Fe}^{2+} \cdot \mathrm{kg}^{-1}, 226.2$ and $55.3 \mu \mathrm{mol} \mathrm{TE} \cdot \mathrm{g}^{-1}$ for FRAP, DPPH and ABTS, respectively), together with both roses and G. sylvaticum, whereas poor antioxidant activity was recorded in the flowers of T. officinale, R. pseudoacacia and A. ursinum. Generally, as well as for TPC, peony and rose showed high antioxidant activity also in a previous study, where these species outperformed other eight Chinese flowers (Xiong et al., 2014). In the case of FRAP analysis, our range of values recorded in 26 species is wider than that reported for 51 fresh edible flowers from China ( $\mathrm{Li}$ et al., 2014), where nonetheless Rosa $\times$ hybrida had the highest activity $\left(178 \mathrm{mmol} \mathrm{Fe}{ }^{2+} \cdot \mathrm{kg}^{-1}\right)$, while the range of antioxidant activity measured with ABTS is consistent with our results. Comparing the data of single species, the antioxidant activity can be very variable according to the study. For example, our FRAP results on $C$. officinalis and C. intybus are much higher than previous reports on the same fresh flowers, while the results on $S$. nigra and $R$. pseudoacacia are similar (Butnariu and Coradini, 2012; Lim, 2014a; Loizzo et al., 2016). Concerning DPPH, our data on cultivated species $C$. officinalis, T. patula and T. majus are sensibly lower in comparison with the literature (Lim, 2014a; Petrova et al., 2016). Finally, Lim (2014b) reported values seven-fold higher than ours in fresh T. majus evaluating antioxidant activity with ABTS test, while 12 rose cultivars from Israel had minor values $\left(2-36 \mu \mathrm{mol} \mathrm{TE} \cdot \mathrm{g}^{-1}\right)$ than our wild edible flowers of $R$. canina and $R$. pendulina (Friedman et al., 2010). It is thereby clear that even 
Table 3. Dry matter, TPC and antioxidant activity (FRAP, DPPH and ABTS assays) in the 26 edible flowers.

\begin{tabular}{|c|c|c|c|c|c|}
\hline \multirow[t]{2}{*}{ Species } & \multirow{2}{*}{$\begin{array}{l}\text { Dry matter } \\
(\%)\end{array}$} & \multirow{2}{*}{$\begin{array}{c}\text { TPC } \\
\left(\mathrm{mg} \mathrm{GAE} \cdot 100 \mathrm{~g}^{-1}\right)\end{array}$} & \multicolumn{3}{|c|}{ Antioxidant activity } \\
\hline & & & $\begin{array}{c}\text { FRAP } \\
\left(\mathrm{mmol} \mathrm{Fe}{ }^{2+} \cdot \mathrm{kg}^{-1}\right)\end{array}$ & $\begin{array}{c}\text { DPPH } \\
\left(\mathrm{mmol} \mathrm{TE} \cdot \mathrm{g}^{-1}\right)\end{array}$ & $\begin{array}{c}\text { ABTS } \\
\left(\mathrm{mmol} \mathrm{TE} \cdot \mathrm{g}^{-1}\right) \\
\end{array}$ \\
\hline Allium ursinum & $10.2 \mathrm{jk}$ & $184.4 \mathrm{k}$ & $4.2 \mathrm{j}$ & $7.6 \mathrm{kl}$ & $0.7 \mathrm{~m}$ \\
\hline Bellis perennis & $16.9 \mathrm{ef}$ & $396.3 \mathrm{gi}$ & $81.6 \mathrm{cf}$ & $24.3 \mathrm{i}$ & $13.4 \mathrm{hj}$ \\
\hline Centaurea cyanus & $26.4 \mathrm{~b}$ & $378.5 \mathrm{hi}$ & $68.3 \mathrm{df}$ & $23.6 \mathrm{i}$ & $17.8 \mathrm{fh}$ \\
\hline Cichorium intybus & $17.3 \mathrm{ef}$ & $618.4 \mathrm{df}$ & $138.4 \mathrm{ad}$ & $69.2 \mathrm{f}$ & $26.9 \mathrm{~d}$ \\
\hline Dianthus carthusianorum & $27.8 \mathrm{ab}$ & $936.3 \mathrm{bd}$ & $222.2 \mathrm{ab}$ & $81.1 \mathrm{ef}$ & $33.6 \mathrm{c}$ \\
\hline Dianthus pavonius & $21.2 \mathrm{~cd}$ & $752.8 \mathrm{ce}$ & $176.1 \mathrm{ac}$ & $106.5 \mathrm{c}$ & $24.3 \mathrm{de}$ \\
\hline Erythronium dens-canis & $15.1 \mathrm{fh}$ & $364.3 \mathrm{hi}$ & $53.5 \mathrm{eg}$ & $20.4 \mathrm{ik}$ & $14.4 \mathrm{hj}$ \\
\hline Geranium sylvaticum & $12.8 \mathrm{i}$ & $1,267.8 \mathrm{ab}$ & $267.0 \mathrm{ab}$ & $152.9 \mathrm{~b}$ & $55.2 \mathrm{a}$ \\
\hline Lavandula angustifolia & $31.2 \mathrm{a}$ & 396.0 gi & 89.5 ce & 14.8 il & $14.0 \mathrm{hj}$ \\
\hline Leucanthemum vulgare & $17.0 \mathrm{ef}$ & $448.8 \mathrm{fi}$ & $44.3 \mathrm{eh}$ & $20.9 \mathrm{ik}$ & $10.8 \mathrm{ij}$ \\
\hline Mentha aquatica & $22.3 \mathrm{c}$ & $1,061.7 \mathrm{bc}$ & $256.0 \mathrm{ab}$ & $86.7 \mathrm{de}$ & $42.5 \mathrm{~b}$ \\
\hline Paeonia officinalis & $13.9 \mathrm{gi}$ & $1,930.5 \mathrm{a}$ & $303.8 \mathrm{a}$ & $226.2 \mathrm{a}$ & $55.3 \mathrm{a}$ \\
\hline Primula veris & $18.8 \mathrm{de}$ & $1,044.9 \mathrm{bc}$ & $230.1 \mathrm{ab}$ & $97.1 \mathrm{~cd}$ & $38.5 \mathrm{bc}$ \\
\hline Primula vulgaris & $9.8 \mathrm{jk}$ & $602.9 \mathrm{dg}$ & $127.4 \mathrm{bd}$ & $41.7 \mathrm{gh}$ & $21.5 \mathrm{df}$ \\
\hline Robinia pseudoacacia & $12.9 \mathrm{i}$ & $203.8 \mathrm{jk}$ & $15.7 \mathrm{i}$ & 4.51 & $2.4 \mathrm{~m}$ \\
\hline Rosa canina & $16.7 \mathrm{ef}$ & $1,396.6 \mathrm{ab}$ & $257.5 \mathrm{ab}$ & $146.2 \mathrm{~b}$ & $55.6 \mathrm{a}$ \\
\hline Rosa pendulina & $21.6 \mathrm{~cd}$ & $1,773.7 \mathrm{a}$ & $253.8 \mathrm{ab}$ & $154.3 \mathrm{~b}$ & $55.7 \mathrm{a}$ \\
\hline Salvia pratensis & $17.7 \mathrm{ef}$ & $314.7 \mathrm{ij}$ & $38.9 \mathrm{fh}$ & $8.9 \mathrm{jl}$ & $9.0 \mathrm{jl}$ \\
\hline Sambucus nigra & $16.8 \mathrm{ef}$ & $508.7 \mathrm{eh}$ & $78.8 \mathrm{cf}$ & 28.5 hi & $18.3 \mathrm{fh}$ \\
\hline Taraxacum officinale & $16.5 \mathrm{ef}$ & $159.4 \mathrm{k}$ & $13.0 \mathrm{i}$ & $7.7 \mathrm{kl}$ & $3.3 \mathrm{~lm}$ \\
\hline Trifolium alpinum & $10.0 \mathrm{jk}$ & $464.6 \mathrm{fi}$ & 91.5 ce & $50.3 \mathrm{gh}$ & $20.3 \mathrm{eg}$ \\
\hline Viola odorata & $13.0 \mathrm{hi}$ & $428.4 \mathrm{fi}$ & $66.1 \mathrm{dg}$ & $22.6 \mathrm{ij}$ & $15.6 \mathrm{gi}$ \\
\hline Borago officinalis ${ }^{\S}$ & $15.3 \mathrm{fg}$ & $163.4 \mathrm{k}$ & $29.7 \mathrm{gi}$ & $22.8 \mathrm{i}$ & $3.7 \mathrm{~km}$ \\
\hline Calendula officinalis ${ }^{\S}$ & $13.7 \mathrm{gi}$ & $189.6 \mathrm{k}$ & $22.6 \mathrm{hi}$ & 3.61 & $9.2 \mathrm{jk}$ \\
\hline Tagetes patula & $10.7 \mathrm{j}$ & $470.8 \mathrm{fi}$ & $143.9 \mathrm{ad}$ & $44.1 \mathrm{gh}$ & $23.0 \mathrm{df}$ \\
\hline Tropaeolum majus ${ }^{\S}$ & $8.9 \mathrm{k}$ & $355.8 \mathrm{hi}$ & $45.3 \mathrm{eh}$ & $14.8 \mathrm{il}$ & $12.8 \mathrm{hj}$ \\
\hline$p$ & $* * *$ & $* * *$ & $* * *$ & $* * *$ & $* * *$ \\
\hline
\end{tabular}

Data are expressed on a fresh-weight basis, except for dry matter. The level of statistical significance is given $(* * * p<0.001)$, different letters inside a column indicate significant differences between species according to Tukey's post-hoc test $(p<0.05)$.

ABTS, 2,2'-azino-bis-3-ethylbenzthiazoline-6-sulfonic acid; DPPH, 2,2-diphenyl-1-picrylhydrazyl; FRAP, ferric reducing antioxidant power; GAE, gallic acid equivalents; TPC, total polyphenol content; TE, trolox equivalents.

${ }^{\S}$ Flowers sampled from cultivated plants.

inside the same species, a wide range of results can be recorded on fresh flowers, possibly due to the growing conditions and the senescence of the plants (Fernandes et al., 2017; Piccolella et al., 2018). The production of secondary metabolites in plants is in fact regulated by various factors, triggered by both endogenous and exogenous signals. The quality and amount of plant secondary metabolites can be thus genetic-dependent as well as environment-dependent (Sangwan et al., 2001; Cutler et al., 2010; Akula and Ravishankar, 2011; Loreto et al., 2014; Ashraf et al., 2018; Caser et al., 2019; Najar et al., 2019).

Different analytical assays are necessary to explain the antioxidant potential of matrices, including TPC, FRAP, DPPH and ABTS, and comparison with other studies can be difficult due to differences in sample processing and extraction techniques (Santos-Buelga et al., 2012). To rank the flower species within our study according to their antioxidant potential, RACI was calculated, being a numerical scale that integrates different analytical methods (Sun and Tanumihardjo, 2007). The ranking of species antioxidant potential based on the calculated RACI is displayed in Figure 1, from the highest values of $P$. officinalis (2.32), R. pendulina (1.81), R. canina (1.59) and G. sylvaticum (1.58), to the lowest of $R$. pseudoacacia (-1.02), T. officinale (-1.02) and $A$. ursinum (-1.07).

The intake of polyphenols and antioxidants in the diet was associated with decreased inflammatory biomarkers (Maleki et al., 2019) and has been positively linked to a reduction of cardiovascular diseases and an improvement in microvascular function in hypertensive patients (Durazzo et al., 2019). High polyphenol intake has been also related to a reduced incidence of diabetes and a chemopreventive efficacy against experimental tumours, despite clinical results not providing univocal results (Li et al., 2013; Durazzo et al., 2019; Kumar and Goel, 2019; Lapuente et al., 2019). Phenolic compounds could also affect the gut microbiota composition, resulting in a greater abundance of beneficial microbes 


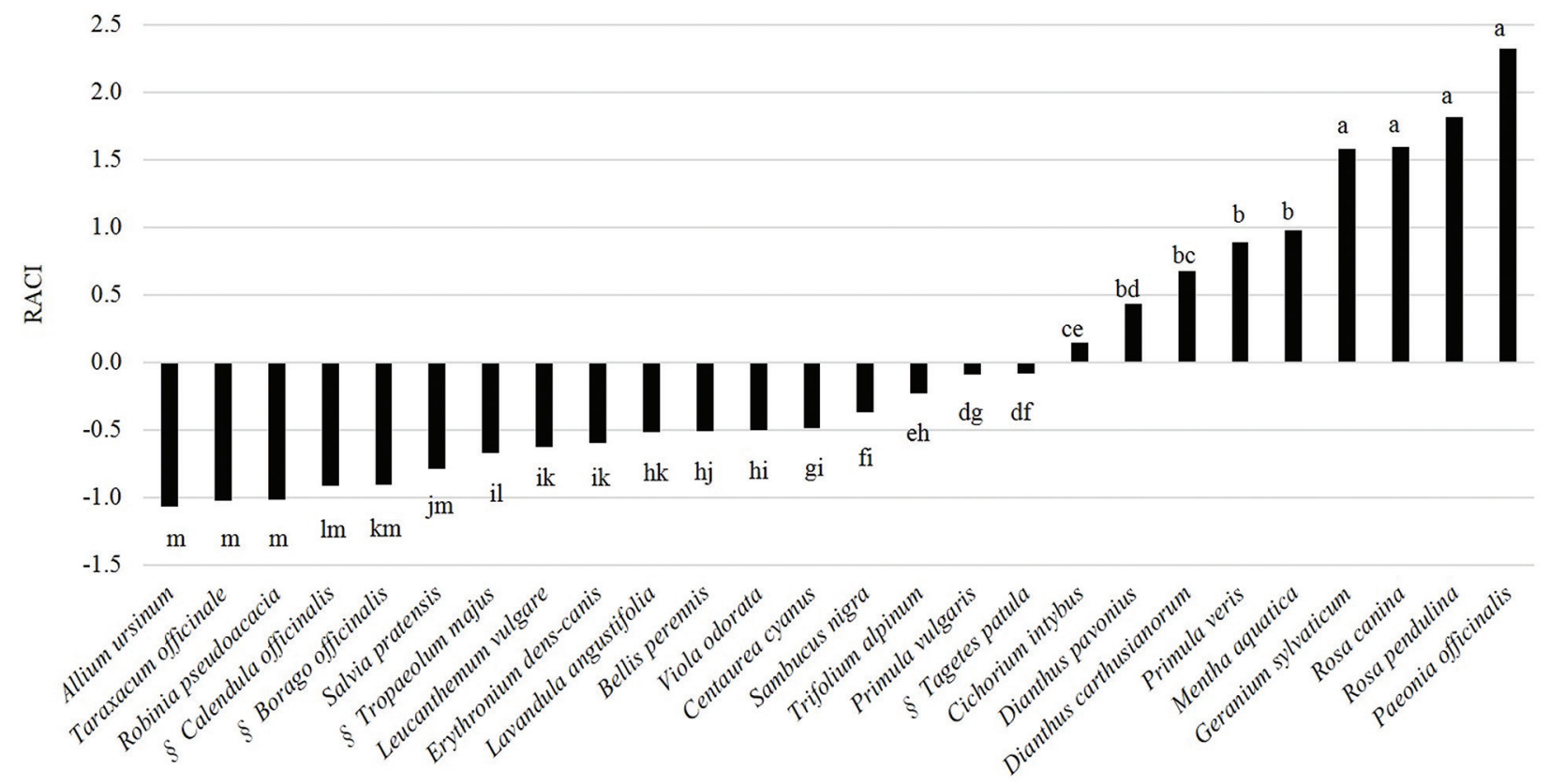

Figure 1. RACI calculated for the 26 studied flower species. Different lower case letters indicate significant differences between species according to Kruskal-Wallis' stepwise comparison $(p<0.05)$. RACI, relative antioxidant capacity index. ${ }^{\S}$ Flowers sampled from cultivated plants.

(Rinninella et al., 2019). Our screening of the TPC and antioxidant activity of 26 different flower species allowed to identify interesting wild plants with edible flowers, that is, P. officinalis and G. sylvaticum, together with more known species, namely roses, showing values always higher than cultivated flowers (B. officinalis, $C$. officinalis, T. patula and T. majus).

\section{Phenolic profiles}

Phenolics, with more than 8,000 compounds, are among the most numerous class of secondary metabolites, leading to a complex classification. However, they can be divided into flavonoids (including flavanols and flavonols, among the others) and non-flavonoid polyphenols (including phenolic acids) (Del Rio et al., 2013; Durazzo et al., 2019). HPLC analysis was performed to determine the phenolic compounds that mainly contributed to the antioxidant capacity of edible flowers, by evaluating the amount of six phenolic acids (four cinnamic and two benzoic acids), five flavonols and two flavanols (catechins), being among the most important compounds due to their biological and antioxidant activities (Durazzo et al., 2019; Takahashi et al., 2020). The results highlighted that each flower has a peculiar phenolic composition and the sum of detected polyphenols varied to a wide extent (Figure 2). Dianthus pavonius and $R$. pendulina had the highest content (2,522.1 and 2,365.7 $\mathrm{mg} \cdot 100 \mathrm{~g}^{-1}$, respectively), with values significantly higher than the species belonging to the same genus, that is, $D$. carthusianorum $\left(772.7 \mathrm{mg} \cdot 100 \mathrm{~g}^{-1}\right)$ and $R$. canina $\left(898.9 \mathrm{mg} \cdot 100 \mathrm{~g}^{-1}\right)$, respectively. The cultivated species, except for T. majus, had a lower content of phenolic compounds than the wild edible flowers analysed. The lowest quantity of polyphenols was indeed recorded in $C$. officinalis $\left(17.3 \mathrm{mg} \cdot 100 \mathrm{~g}^{-1}\right)$.

The flowers with the highest RACI, that is, $P$. officinalis, R. canina, R. pendulina and $G$. sylvaticum had a statistically different amount of polyphenols detected with the chromatographic analysis, being 1,172, 899, 2,366 and $694 \mathrm{mg} \cdot 100 \mathrm{~g}^{-1}$, respectively. Conversely, the high amounts of phenolics detected in D. pavonius and T. majus did not correspond to high RACI, indicating that further studies are needed to fully understand the phytochemical profile of each species and identify all the molecules that contribute to the antioxidant activity.

Considering each class of polyphenols, flavonols were on average $346 \mathrm{mg} \cdot 100 \mathrm{~g}^{-1}$, cinnamic acids $183 \mathrm{mg} \cdot 100 \mathrm{~g}^{-1}$, benzoic acid $133 \mathrm{mg} \cdot 100 \mathrm{~g}^{-1}$ and catechins $114 \mathrm{mg} \cdot 100 \mathrm{~g}^{-1}$, confirming that flavonols are the main phenolics in edible flowers (Pires et al., 2019). Interestingly, analysing the Phenol-Explorer Database on 452 foods and beverages, Pérez-Jiménez et al. (2010) found a mean content of flavonols, benzoic acids and cinnamic acids equal to 11,29 , and $35 \mathrm{mg} \cdot 100 \mathrm{~g}^{-1}$ of FW, respectively, values considerably lower in comparison with edible flowers.

The detailed results on each class of polyphenols are reported in the following sections.

\section{Flavonols}

The evaluated flavonols (Figure 2 and Table 4; Figure A1 in Appendix) were present in 23 species, lacking in B. perennis, B. officinalis and S. pratensis. 


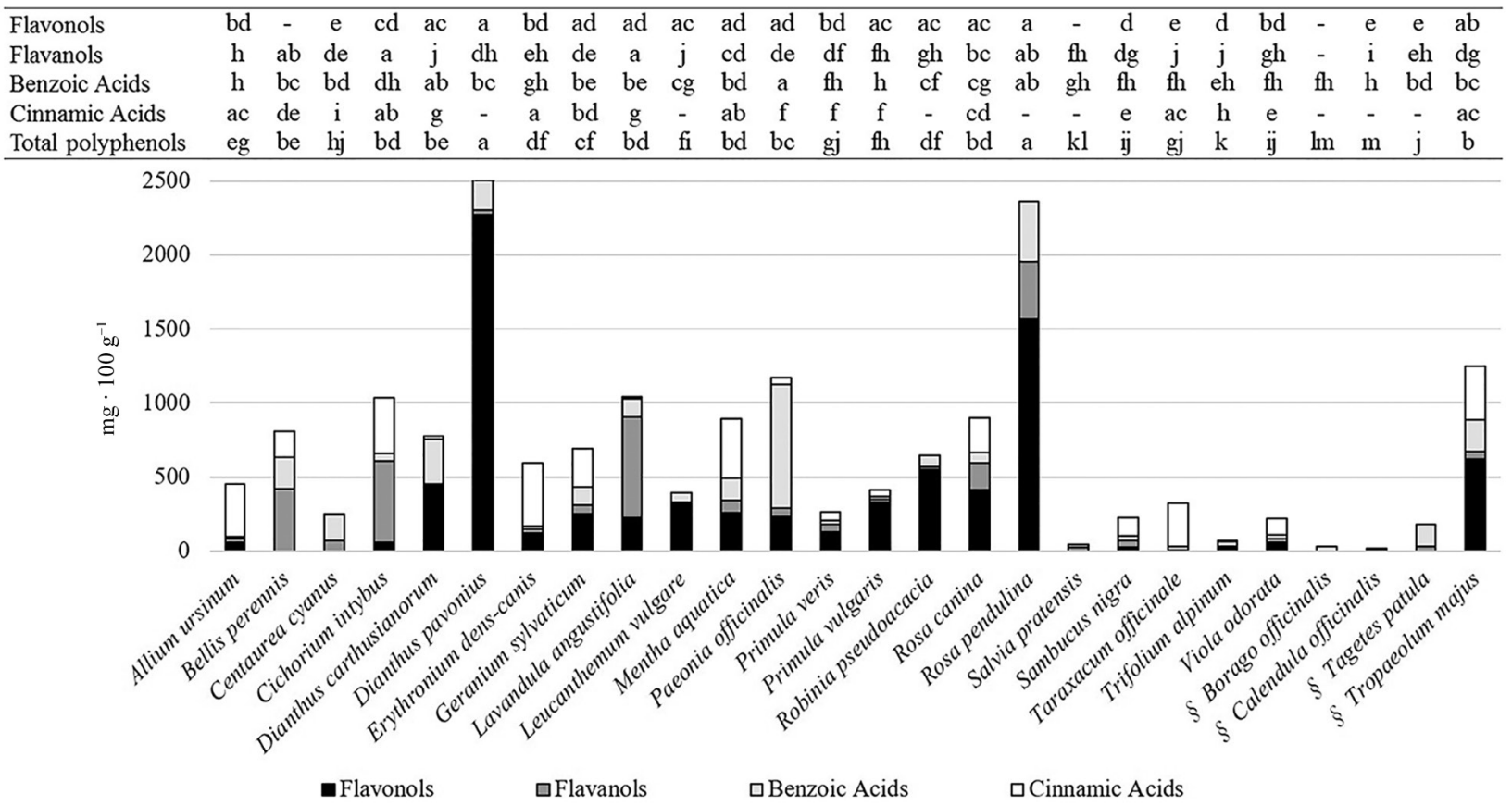

Figure 2. Total polyphenols and polyphenol classes (flavonols, flavanols, benzoic acids and cinnamic acids) content $\left(\mathrm{mg} \cdot 100 \mathrm{~g}^{-1}\right)$ in the flowers of the 26 studied species. Different lower case letters in a row indicate significant differences between species according to Tukey's post-hoc test $(p<0.05)$. - , compound not detected. ${ }^{\S}$ Flowers sampled from cultivated plants.

Where recorded, this class of flavonoids ranged from $0.5 \mathrm{mg} \cdot 100 \mathrm{~g}^{-1}$ (T. patula) and 2,269.6 $\mathrm{mg} \cdot 100 \mathrm{~g}^{-1}$ (D. pavonius), always showing significant differences between species. Our range is particularly relevant, considering that the highest concentrations of flavonols in foods are $73-158 \mathrm{mg} \cdot 100 \mathrm{~g}^{-1} \mathrm{FW}$ in onion and shallot, $119 \mathrm{mg} \cdot 100 \mathrm{~g}^{-1} \mathrm{FW}$ in spinach, and $88 \mathrm{mg} \cdot 100 \mathrm{~g}^{-1} \mathrm{FW}$ in black chokeberry (Pérez-Jiménez et al., 2010).

Considering single compounds (Table 4; Figure A1 in Appendix), hyperoside was detected in 13 out of 26 species, ranging from $0.6 \mathrm{mg} \cdot 100 \mathrm{~g}^{-1}$ (G. sylvaticum and T. officinale) to $262.4 \mathrm{mg} \cdot 100 \mathrm{~g}^{-1}$ (D. carthusianorum). Isoquercitrin was found in 11 species, ranging from $7.9 \mathrm{mg} \cdot 100 \mathrm{~g}^{-1}$ (T. alpinum) to $2,072.0 \mathrm{mg} \cdot 100 \mathrm{~g}^{-1}$ (D. pavonius). Quercetin was recorded in seven species, from $0.7 \mathrm{mg} \cdot 100 \mathrm{~g}^{-1}$ (T. officinale) to $328.1 \mathrm{mg} \cdot 100 \mathrm{~g}^{-1}$ (L. vulgare). Quercitrin was detected in 17 species, from $0.9 \mathrm{mg} \cdot 100 \mathrm{~g}^{-1}$ (A. ursinum and C. cyanus) to $1,353.4 \mathrm{mg} \cdot 100 \mathrm{~g}^{-1}$ (R. pendulina). Finally, rutin was found in 14 species, from $0.5 \mathrm{mg} \cdot 100 \mathrm{~g}^{-1}$ (T. officinale, T. alpinum, and T. patula) to $107.7 \mathrm{mg} \cdot 100 \mathrm{~g}^{-1}$ (P. vulgaris).

Considering each species, A. ursinum had very poor content of flavonols $\left(59.4 \mathrm{mg} \cdot 100 \mathrm{~g}^{-1}\right)$, with hyperoside being the most abundant (Table 4). Exploring comparable bibliography, our findings on $B$. perennis were concordant with previous studies (Nazaruk and Gudej, 2001; Kucekova et al., 2013), since no amounts or very low amounts of quercetin and rutin were detected in the flower extract. In C. cyanus, only quercitrin is present, in extremely low amounts $\left(0.9 \mathrm{mg} \cdot 100 \mathrm{~g} \mathrm{~g}^{-1}\right)$.
Cichorium intybus is very poor in flavonols, lacking in quercetin and quercitrin, concordant with a previous study (Kucekova et al., 2013), where also no amount of rutin was recorded; conversely, Loizzo et al. (2016) found very high concentrations of rutin (about $2,000 \mathrm{mg} \cdot 100 \mathrm{~g}^{-1}$ of dry extract) in C. intybus. Dianthus spp. were very rich but had diverse content of total flavonols, with $D$. carthusianorum having the highest concentration of hyperoside among the 26 studied species and $D$. pavonius the highest of isoquercitrin. Erythronium dens-canis was poor in flavonols with quercitrin as the highest $\left(108.5 \mathrm{mg} \cdot 100 \mathrm{~g}^{-1}\right)$. The extract of $G$. sylvaticum was the only one to include all the five studied flavonols, containing about $250 \mathrm{mg} \cdot 100 \mathrm{~g}^{-1}$ of compounds. Similar concentrations were also recorded in L. angustifolia, L. vulgare, M. aquatica, and $P$. officinalis, where quercetin was the predominant compound. As for Primula spp., P. vulgaris flowers were slightly higher in flavonols than $P$. veris, also showing the highest concentration of rutin. Only one flavonol (quercitrin) was detected in $R$. pseudoacacia, as also occurring in S. nigra, C. officinalis and T. majus, with the first and the latter showing very high contents (547.3 and $619.6 \mathrm{mg} \cdot 100 \mathrm{~g}^{-1}$ ). Contrasting results have been previously reported in $R$. pseudoacacia and $S$. nigra: Loizzo et al. (2016) found very high concentrations of rutin (about $2,000 \mathrm{mg} \cdot 100 \mathrm{~g}^{-1}$ of dry extract) in both species and of quercetin in $S$. nigra, while no traces of quercetin were found by Kucekova et al. (2013) in $S$. nigra, as our results. Concerning roses, $R$. pendulina was very rich in flavonols $\left(1,566.2 \mathrm{mg} \cdot 100 \mathrm{~g}^{-1}\right)$ 
Table 4. Flavonols and flavanols content $\left(\mathrm{mg} \cdot 100 \mathrm{~g}^{-1}\right)$ in the flowers of the 26 studied species.

\begin{tabular}{|c|c|c|c|c|c|c|c|}
\hline \multirow[t]{2}{*}{ Species } & \multicolumn{5}{|c|}{ Flavonols } & \multicolumn{2}{|c|}{ Flavanols } \\
\hline & Hyperoside & Isoquercitrin & Quercetin & Quercitrin & Rutin & Catechin & Epicatechin \\
\hline Allium ursinum & $38.7 \mathrm{~b}$ & $0.0-$ & $0.0-$ & $0.9 \mathrm{c}$ & $19.7 \mathrm{~b}$ & $0.0-$ & $20.8 \mathrm{~g}$ \\
\hline Bellis perennis & $0.0-$ & $0.0-$ & $0.0-$ & $0.0-$ & $0.0-$ & $0.4 \mathrm{~d}$ & $421.0 \mathrm{a}$ \\
\hline Centaurea cyanus & $0.0-$ & $0.0-$ & $0.0-$ & $0.9 \mathrm{c}$ & $0.0-$ & $0.0-$ & $65.2 \mathrm{c}$ \\
\hline Cichorium intybus & $23.5 \mathrm{bc}$ & $16.1 \mathrm{c}$ & $0.0-$ & $0.0-$ & $13.7 \mathrm{~b}$ & $19.1 \mathrm{bc}$ & $533.3 \mathrm{a}$ \\
\hline Dianthus carthusianorum & $262.4 \mathrm{a}$ & $163.6 \mathrm{~b}$ & $0.0-$ & $8.0 \mathrm{c}$ & $17.8 \mathrm{~b}$ & $0.0-$ & $0.1 \mathrm{~h}$ \\
\hline Dianthus pavonius & $0.0-$ & $2,072.0 \mathrm{a}$ & $0.0-$ & $163.6 \mathrm{c}$ & $34.1 \mathrm{~b}$ & $11.7 \mathrm{c}$ & $26.3 \mathrm{dg}$ \\
\hline Erythronium dens-canis & $9.0 \mathrm{~cd}$ & $0.0-$ & $0.0-$ & $108.5 \mathrm{c}$ & $0.5 \mathrm{c}$ & $0.4 \mathrm{~d}$ & $29.9 \mathrm{cg}$ \\
\hline Geranium sylvaticum & $0.6 \mathrm{e}$ & $12.5 \mathrm{c}$ & $189.0 \mathrm{a}$ & $34.5 \mathrm{c}$ & $17.1 \mathrm{~b}$ & $20.7 \mathrm{bc}$ & $37.7 \mathrm{cg}$ \\
\hline Lavandula angustifolia & $17.3 \mathrm{bd}$ & $0.0-$ & $207.3 \mathrm{a}$ & $0.0-$ & $0.0-$ & $375.6 \mathrm{a}$ & $306.6 \mathrm{ab}$ \\
\hline Leucanthemum vulgare & $0.0-$ & $0.0-$ & $328.1 \mathrm{a}$ & $0.0-$ & $0.0-$ & $0.0-$ & $0.1 \mathrm{~h}$ \\
\hline Mentha aquatica & $0.0-$ & $12.0 \mathrm{c}$ & $227.2 \mathrm{a}$ & $0.0-$ & $16.8 \mathrm{~b}$ & $24.0 \mathrm{bc}$ & $59.2 \mathrm{~cd}$ \\
\hline Paeonia officinalis & $0.0-$ & $0.0-$ & $216.3 \mathrm{a}$ & $16.4 \mathrm{c}$ & $0.0-$ & $28.6 \mathrm{~b}$ & $30.7 \mathrm{cg}$ \\
\hline Primula veris & $14.7 \mathrm{bd}$ & $10.8 \mathrm{c}$ & $0.0-$ & $82.3 \mathrm{c}$ & $18.1 \mathrm{~b}$ & $0.4 \mathrm{~d}$ & $52.0 \mathrm{ce}$ \\
\hline Primula vulgaris & $9.4 \mathrm{~cd}$ & $100.1 \mathrm{~b}$ & $0.0-$ & $109.6 \mathrm{c}$ & $107.7 \mathrm{a}$ & $0.0-$ & $23.9 \mathrm{eg}$ \\
\hline Robinia pseudoacacia & $0.0-$ & $0.0-$ & $0.0-$ & $547.3 \mathrm{~b}$ & $0.0-$ & $0.0-$ & $22.0 \mathrm{fg}$ \\
\hline Rosa canina & $38.5 \mathrm{~b}$ & $130.2 \mathrm{~b}$ & $205.7 \mathrm{a}$ & $35.9 \mathrm{c}$ & $0.0-$ & $26.0 \mathrm{~b}$ & $158.1 \mathrm{~b}$ \\
\hline Rosa pendulina & $15.3 \mathrm{bd}$ & $184.5 \mathrm{~b}$ & $0.0-$ & $1,353.4 \mathrm{a}$ & $12.9 \mathrm{~b}$ & $0.4 \mathrm{~d}$ & $388.4 \mathrm{~b}$ \\
\hline Salvia pratensis & $0.0-$ & $0.0-$ & $0.0-$ & $0.0-$ & $0.0-$ & $0.0-$ & $25.0 \mathrm{eg}$ \\
\hline Sambucus nigra & $0.0-$ & $0.0-$ & $0.0-$ & $23.4 \mathrm{c}$ & $0.0-$ & $0.0-$ & $48.3 \mathrm{cf}$ \\
\hline Taraxacum officinale & $0.6 \mathrm{e}$ & $0.0-$ & $0.7 \mathrm{~b}$ & $0.0-$ & $0.5 \mathrm{c}$ & $0.0-$ & $0.1 \mathrm{~h}$ \\
\hline Trifolium alpinum & $7.4 \mathrm{~d}$ & $7.9 \mathrm{c}$ & $0.0-$ & $13.5 \mathrm{c}$ & $0.5 \mathrm{c}$ & $0.0-$ & $0.1 \mathrm{~h}$ \\
\hline Viola odorata & $16.3 \mathrm{bd}$ & $15.7 \mathrm{c}$ & $0.0-$ & $10.8 \mathrm{c}$ & $14.4 \mathrm{~b}$ & $0.0-$ & $21.9 \mathrm{fg}$ \\
\hline Borago officinalis & $0.0-$ & $0.0-$ & $0.0-$ & $0.0-$ & $0.0-$ & $0.0-$ & $0.0-$ \\
\hline Calendula officinalis ${ }^{\S}$ & $0.0-$ & $0.0-$ & $0.0-$ & $1.7 \mathrm{c}$ & $0.0-$ & $0.4 \mathrm{~d}$ & $0.1 \mathrm{~h}$ \\
\hline Tagetes patula & $0.0-$ & $0.0-$ & $0.0-$ & $0.0-$ & $0.5 \mathrm{c}$ & $0.0-$ & $29.3 \mathrm{cg}$ \\
\hline Tropaeolum majus & $0.0-$ & $0.0-$ & $0.0-$ & $619.6 \mathrm{~b}$ & $0.0-$ & $0.0-$ & $49.1 \mathrm{cf}$ \\
\hline
\end{tabular}

Different lower case letters in a column indicate significant differences between species according to Tukey's post-hoc test $(p<0.05)$. Data are means of three biological replicates.

-, compound not detected.

§Flowers sampled from cultivated plants.

but lacked in quercetin and $R$. canina lacked in rutin. A previous report on roses ( $R$. damascena, $R$. bourboniana and $R$. brunonii) instead identified both compounds, together with quercitrin (Kumar et al., 2009). Flowers of T. officinale had the lower content of flavonols $\left(<1.7 \mathrm{mg} \cdot 100 \mathrm{~g}^{-1}\right)$, similar to C. cyanus, $C$. officinalis and T. patula, which had only traces of rutin. Also T. alpinum was poor in flavonols, with quercitrin as the most abundant compound (13.5 mg $\left.\cdot 100 \mathrm{~g}^{-1}\right)$. The flowers of $V$. odorata contained a concentration of flavonols similar to A. ursinum, E. dens-canis and $P$. veris. Quercetin and rutin have been previously found in Viola tricolor $\mathrm{L}$. and Viola $\times$ wittrockiana Gams., as well as rutin in $V$. tricolor (Vukics et al., 2008; Gamsjaeger et al., 2011; Gonçalves et al., 2012; Skowyra et al., 2014).

Flavonols seem to be the main phenolics exerting anti-cancer activity in vitro (Li et al., 2013) and inhibit in vitro oxidation of low-density lipoproteins, reducing thrombotic tendency (Del Rio et al., 2013). Among flavonols, quercetin represents an important molecule with wide therapeutic applications, owing to its anticancer and anti-inflammatory activity, together with cardiovascular disease and diabetes prevention
(Durazzo et al., 2019). Thereof, L. vulgare and the species with a similar amount of quercetin (G. sylvaticum, $L$. angustifolia, $M$. aquatica, $P$. officinalis, and $R$. canina) are very interesting, as well as $R$. pseudoacacia and $T$. majus, for their amount of quercitrin, while $D$. pavonius and $R$. pendulina deserve attention for their impressive concentration of total flavonols.

\section{Flavanols}

Flavanols (Figure 2 and Table 4; Figure A2 in Appendix) were present in the flowers of all the studied species, except for B. officinalis, ranging from $0.1 \mathrm{mg} \cdot 100 \mathrm{~g}^{-1}$ (D. carthusianorum, L. vulgare, T. officinale, and $T$. alpinum) to $682.3 \mathrm{mg} \cdot 100 \mathrm{~g}^{-1}$ (L. angustifolia) with significant differences between species. At present, flavanols have been detected in 84 out of 452 foods (Pérez-Jiménez et al., 2010) and the richest sources are nuts (181-496 mg $\cdot 100 \mathrm{~g}^{-1} \mathrm{FW}$ ), strawberry (148 mg $\cdot 100 \mathrm{~g}^{-1} \mathrm{FW}$ ), and above all, berries, with content up to $659 \mathrm{mg} \cdot 100 \mathrm{~g}^{-1} \mathrm{FW}$, comparable with our highest values.

Catechin (Table 4; Figure A2 in Appendix) occurred in 12 species, from $0.4 \mathrm{mg} \cdot 100 \mathrm{~g}^{-1}$ (B. perennis, E. dens-canis, $P$. veris, $R$. pendulina, and $C$. officinalis) 
to $375.6 \mathrm{mg} \cdot 100 \mathrm{~g}^{-1}$ (L. angustifolia). Epicatechin was instead more frequent, occurring in 25 species with a range of $0.1 \mathrm{mg} \cdot 100 \mathrm{~g}^{-1}$ (D. carthusianorum, $L$. vulgare, T. officinale, T. alpinum, and C. officinalis) and $533.3 \mathrm{mg} \cdot 100 \mathrm{~g}^{-1}$ (C. intybus).

The flavanols content was generally below $100 \mathrm{mg} \cdot 100 \mathrm{~g}^{-1}$ in most of the species, while interesting results are shown by five flowers, in which epicatechin always prevailed on catechin. Lavandula angustifolia, $C$. intybus, $B$. perennis and $R$. pendulina were around or above $400 \mathrm{mg} \cdot 100 \mathrm{~g}^{-1}$, while $R$. canina had half of the content $\left(184 \mathrm{mg} \cdot 100 \mathrm{~g}^{-1}\right)$. Lavandula angustifolia was the only species to contain a high concentration of catechin. Comparing bibliography, our findings in $B$. perennis, $S$. nigra and $T$. officinale are consistent with Kucekova et al. (2013), where no amounts of catechin were detected. The same authors found zero and $38 \mathrm{mg} \cdot 100 \mathrm{~g}^{-1}$ of dry weight of catechin in C. intybus and S. pratensis, respectively, and López-García et al. (2013) also found a small amount of catechin in $S$. pratensis (3.76 mg $\cdot 100 \mathrm{~g}^{-1}$ of dry weight). These results differ from our data since we recorded $19.1 \mathrm{mg} \cdot 100 \mathrm{~g}^{-1}$ in C. intybus and no detection in $S$. pratensis. Previous information on S. nigra (Młynarczyk et al., 2018) evidenced the presence of epicatechin in the flowers $\left(25.43 \mathrm{mg} \cdot 100 \mathrm{~g}^{-1}\right.$ FW) and of catechin $0.68 \mathrm{mg} \cdot 100 \mathrm{~g}^{-1} \mathrm{FW}$, similar to our results on the same species $\left(48.3 \mathrm{mg} \cdot 100 \mathrm{~g}^{-1}\right.$ of epicatechin and $0 \mathrm{mg} \cdot 100 \mathrm{~g}^{-1}$ of catechin).

Catechin and epicatechin belong to the subgroup of monomeric flavanols and are known to help in decreasing the body mass index and waist circumference (Durazzo et al., 2019); moreover, they help in preventing metabolic and cardiovascular diseases by improving the blood flow and exert antimicrobial, antiinflammatory and antidiabetic properties (Ananingsih et al., 2013). Thus $R$. canina, $R$. pendulina, B. perennis, $C$. intybus and above all $L$. angustifolia are interesting genetic resources in this sense, whereas cultivated flowers (B. officinalis and C. officinalis) are of least interest.

\section{Phenolic acids}

Phenolic acids are commonly divided into benzoic and cinnamic acids, wide groups of polyphenols with at least 30 compounds reported in the past 10 years. Phenolic acids are recognized for their radical scavenging activity and their role in food preservation, as well as their therapeutic application, as reducing blood pressure and triglycerides (Kim et al., 2003; Ou and Kwok, 2004; Durazzo et al., 2019).

\section{Benzoic acids}

Benzoic acids (Figure 2 and Table 5; Figure A3 in Appendix) were present in every species ranging from $15.2 \mathrm{mg} \cdot 100 \mathrm{~g}^{-1}$ (C. officinalis) and $833.4 \mathrm{mg} \cdot 100 \mathrm{~g}^{-1}$ (P. officinalis), with significant differences among species. This compound content is interestingly elevated in comparison with foods (Pérez-Jiménez et al., 2010); apart from chestnut $\left(1,215 \mathrm{mg} \cdot 100 \mathrm{~g}^{-1} \mathrm{FW}\right)$, the other foods and beverages had a much lower amount of benzoic acids, that is, raspberry $\left(121 \mathrm{mg} \cdot 100 \mathrm{~g}^{-1} \mathrm{FW}\right)$, pomegranate juice $\left(55 \mathrm{mg} \cdot 100 \mathrm{~g}^{-1} \mathrm{FW}\right)$ and blackberry (50 mg $\left.\cdot 100 \mathrm{~g}^{-1} \mathrm{FW}\right)$.

Ellagic acid was detected in all the species (Table 5; Figure A3 in Appendix), ranging from $0.1 \mathrm{mg} \cdot 100 \mathrm{~g}^{-1}$ (B. officinalis) to $589.2 \mathrm{mg} \cdot 100 \mathrm{~g}^{-1}$ (P. officinalis), while gallic acid was found only in 9 species, with amounts of $0.1 \mathrm{mg} \cdot 100 \mathrm{~g}^{-1}$ (A. ursinum, P. veris, $R$. canina, S. officinalis and $S$. nigra) to $244.2 \mathrm{mg} \cdot 100 \mathrm{~g}^{-1}$ (P. officinalis).

Allium ursinum and other 11 species (C. intybus, E. dens-canis, $P$. veris, $P$. vulgaris, $S$. pratensis, $S$. nigra, T. officinale, T. alpinum, V. odorata, B. officinalis and C. officinalis) had similar concentrations of benzoic acids, up to $51.2 \mathrm{mg} \cdot 100 \mathrm{~g}^{-1}$, with prevalence of ellagic acid, except in $C$. intybus and B. officinalis. A higher amount of benzoic acids was detected in the other species, containing only ellagic acid, except for $D$. carthusianorum and $R$. canina that had $27.5 \mathrm{mg} \cdot 100 \mathrm{~g}^{-1}$ and $0.1 \mathrm{mg} \cdot 100 \mathrm{~g}^{-1}$ of gallic acid, together with $P$. officinalis where the highest amount was measured. Gallic acid has been previously identified (18-458 mg · $100 \mathrm{~g}^{-1}$ ) in B. perennis, Rosa spp., S. pratensis, S. nigra, T. patula, T. officinale and T. majus (Kumar et al., 2009; Kucekova et al., 2013; López-García et al., 2013; Lim, 2014a, 2014b), opposite to our study, where this compound is absent or present only in traces in the same species.

Gallic acid is mainly known for its antioxidant activity, while ellagic acid has anti-inflammatory properties and both exert anticancer and anti-HIV replication activities (Landete, 2011). Ellagic acid is also important in reducing the risk of cardiovascular diseases and obesity, since it decreases blood pressure and high blood cholesterol (Durazzo et al., 2019). Flowers of $P$. officinalis are therefore the most promising for these purposes.

\section{Cinnamic acids}

Cinnamic acids (Figure 2 and Table 5; Figure A4 in Appendix) were detected in the flowers of 18 species, ranging from $0.1 \mathrm{mg} \cdot 100 \mathrm{~g}^{-1}$ (C. cyanus) to $423.3 \mathrm{mg}$. $100 \mathrm{~g}^{-1}$ (E. dens-canis). Our highest values are double the foods and beverages with the highest concentrations, namely coffee $\left(212 \mathrm{mg} \cdot 100 \mathrm{~mL}^{-1}\right)$, globe artichoke (202 mg $\left.\cdot 100 \mathrm{~g}^{-1} \mathrm{FW}\right)$, prune $\left(192 \mathrm{mg} \cdot 100 \mathrm{~g}^{-1} \mathrm{FW}\right)$ and red chicory (183 mg · $\left.100 \mathrm{~g}^{-1} \mathrm{FW}\right)$ (Pérez-Jiménez et al., 2010).

Caffeic acid (Table 5; Figure A4 in Appendix) was present in 13 species and ranged from $0.1 \mathrm{mg} \cdot 100 \mathrm{~g}^{-1}(C$. cyanus) to $16.3 \mathrm{mg} \cdot 100 \mathrm{~g}^{-1}$ (P. vulgaris). Chlorogenic acid was detected in 8 species, from $0.2 \mathrm{mg} \cdot 100 \mathrm{~g}^{-1}$ (L. angustifolia) to $275.5 \mathrm{mg} \cdot 100 \mathrm{~g}^{-1}$ (E. dens-canis). Coumaric acid, found in 10 species, varied between 0.5 (A. ursinum and T. alpinum) and $158.5 \mathrm{mg} \cdot 100 \mathrm{~g}^{-1}$ (B. perennis). Finally, ferulic acid was detected in 
Table 5. Benzoic acids and cinnamic acids content $\left(\mathrm{mg} \cdot 100 \mathrm{~g}^{-1}\right)$ in 26 flower species.

\begin{tabular}{|c|c|c|c|c|c|c|}
\hline \multirow[t]{2}{*}{ Species } & \multicolumn{2}{|c|}{ Benzoic acids } & \multicolumn{4}{|c|}{ Cinnamic acids } \\
\hline & Ellagic acid & Gallic acid & Caffeic acid & Chlorogenic acid & Coumaric acid & Ferulic acid \\
\hline Allium ursinum & $15.2 \mathrm{~h}$ & $0.1 \mathrm{c}$ & $0.0-$ & $0.0-$ & $0.5 \mathrm{c}$ & $357.3 \mathrm{a}$ \\
\hline Bellis perennis & $212.9 \mathrm{ad}$ & $0.0-$ & $15.6 \mathrm{ab}$ & $0.0-$ & $158.5 \mathrm{a}$ & $0.0-$ \\
\hline Centaurea cyanus & $180.1 \mathrm{ad}$ & $0.0-$ & $0.1 \mathrm{~d}$ & $0.0-$ & $0.0-$ & $0.0-$ \\
\hline Cichorium intybus & $23.7 \mathrm{fh}$ & $27.5 \mathrm{~b}$ & $0.0-$ & $230.0 \mathrm{~b}$ & $148.5 \mathrm{a}$ & $0.0-$ \\
\hline Dianthus carthusianorum & $278.5 \mathrm{ac}$ & $27.6 \mathrm{~b}$ & $14.6 \mathrm{ab}$ & $0.0-$ & $0.0-$ & $0.0-$ \\
\hline Dianthus pavonius & $214.4 \mathrm{ad}$ & $0.0-$ & $0.0-$ & $0.0-$ & $0.0-$ & $0.0-$ \\
\hline Erythronium dens-canis & $20.4 \mathrm{gh}$ & $0.0-$ & $16.2 \mathrm{a}$ & $275.5 \mathrm{a}$ & $110.7 \mathrm{a}$ & $20.9 \mathrm{bc}$ \\
\hline Geranium sylvaticum & 121.4 be & $0.0-$ & $0.0-$ & $244.1 \mathrm{~b}$ & $16.4 \mathrm{~b}$ & $0.0-$ \\
\hline Lavandula angustifolia & 122.8 be & $0.0-$ & $11.7 \mathrm{c}$ & $0.2 \mathrm{c}$ & $0.0-$ & $0.0-$ \\
\hline Leucanthemum vulgare & $63.2 \mathrm{dg}$ & $0.0-$ & $0.0-$ & $0.0-$ & $0.0-$ & $0.0-$ \\
\hline Mentha aquatica & $153.8 \mathrm{bd}$ & $0.0-$ & $15.9 \mathrm{ab}$ & $270.6 \mathrm{a}$ & $113.8 \mathrm{a}$ & $0.0-$ \\
\hline Paeonia officinalis & $589.2 \mathrm{a}$ & $244.2 \mathrm{a}$ & $13.9 \mathrm{~b}$ & $0.0-$ & $0.0-$ & $32.6 \mathrm{bc}$ \\
\hline Primula veris & $27.9 \mathrm{fh}$ & $0.1 \mathrm{c}$ & $15.2 \mathrm{ab}$ & $0.0-$ & $0.0-$ & $43.9 \mathrm{~b}$ \\
\hline Primula vulgaris & $16.3 \mathrm{~h}$ & $0.0-$ & $16.3 \mathrm{a}$ & $0.0-$ & $0.0-$ & $29.3 \mathrm{bc}$ \\
\hline Robinia pseudoacacia & $79.5 \mathrm{cf}$ & $0.0-$ & $0.0-$ & $0.0-$ & $0.0-$ & $0.0-$ \\
\hline Rosa canina & $72.5 \mathrm{dg}$ & $0.1 \mathrm{c}$ & $0.0-$ & $232.0 \mathrm{~b}$ & $0.0-$ & $0.0-$ \\
\hline Rosa pendulina & $410.7 \mathrm{ab}$ & $0.0-$ & $0.0-$ & $0.0-$ & $0.0-$ & $0.0-$ \\
\hline Salvia pratensis & $20.4 \mathrm{gh}$ & $0.1 \mathrm{c}$ & $0.0-$ & $0.0-$ & $0.0-$ & $0.0-$ \\
\hline Sambucus nigra & $27.1 \mathrm{fh}$ & $0.1 \mathrm{c}$ & $15.3 \mathrm{ab}$ & $0.0-$ & $112.0 \mathrm{a}$ & $0.0-$ \\
\hline Taraxacum officinale & $28.2 \mathrm{fh}$ & $0.0-$ & $15.7 \mathrm{ab}$ & $273.3 \mathrm{a}$ & $0.0-$ & $0.0-$ \\
\hline Trifolium alpinum & $34.6 \mathrm{eh}$ & $0.0-$ & $0.0-$ & $0.0-$ & $0.5 \mathrm{c}$ & $0.2 \mathrm{c}$ \\
\hline Viola odorata & $26.2 \mathrm{fh}$ & $0.0-$ & $1.9 \mathrm{~d}$ & $0.0-$ & $113.4 \mathrm{a}$ & $0.2 \mathrm{c}$ \\
\hline Borago officinalis ${ }^{\S}$ & $0.1 \mathrm{i}$ & $27.9 \mathrm{~b}$ & $0.0-$ & $0.0-$ & $0.0-$ & $0.0-$ \\
\hline Calendula officinalis ${ }^{\S}$ & $15.2 \mathrm{~h}$ & $0.0-$ & $0.0-$ & $0.0-$ & $0.0-$ & $0.0-$ \\
\hline Tagetes patula & $150.1 \mathrm{bd}$ & $0.0-$ & $0.0-$ & $0.0-$ & $0.0-$ & $0.0-$ \\
\hline Tropaeolum majus & $214.3 \mathrm{ad}$ & $0.0-$ & $14.1 \mathrm{~b}$ & $241.2 \mathrm{~b}$ & $109.6 \mathrm{a}$ & $0.0-$ \\
\hline
\end{tabular}

Different lower-case letters in a column indicate significant differences between species according to Tukey's post-hoc test $(p<0.05)$. Data are means of three biological replicates.

-, compound not detected.

§Flowers sampled from cultivated plants.

seven species, from $0.2 \mathrm{mg} \cdot 100 \mathrm{~g}^{-1}$ (T. alpinum and $V$. odorata) to $357.3 \mathrm{mg} \cdot 100 \mathrm{~g}^{-1}$ (A. ursinum).

Table 5 shows that eight species lacked in cinnamic acids (D. pavonius, L. vulgare, $R$. pseudoacacia, $R$. pendulina, $S$. pratensis, B. officinalis, C. officinalis and T. patula), concordant with the results of Kucekova et al. (2013) on S. pratensis. Four species contained only traces $\left(<15 \mathrm{mg} \cdot 100 \mathrm{~g}^{-1}\right.$, C. cyanus, D. carthusianorum, L. angustifolia and T. alpinum), with caffeic acid as the most present. Paeonia officinalis, $P$. veris and $P$. vulgaris had about $50 \mathrm{mg} \cdot 100 \mathrm{~g}^{-1}$ of cinnamic acids, containing only caffeic and ferulic acid, with the first one as the most abundant. With higher amounts, from $100 \mathrm{mg} \cdot 100 \mathrm{~g}^{-1}$ to $300 \mathrm{mg} \cdot 100 \mathrm{~g}^{-1}$, B. perennis, $S$. nigra and $V$. odorata were characterized by the presence of coumaric acid, while G. sylvaticum, R. canina and $T$. officinale were characterized by chlorogenic acid. The five species containing the highest amounts of cinnamic acids had mainly chlorogenic and coumaric acids $(C$. intybus, E. dens-canis, M. aquatica and T. majus), except for $A$. ursinum that contained only ferulic acid and traces of coumaric acid. Contrasting results are reported by the study of Kucekova et al. (2013), where coumaric acid was absent in B. perennis, $C$. intybus and $S$. nigra, conversely to our study; caffeic acid was present in B. perennis, $C$. intybus and $S$. nigra but not in T. officinale and ferulic acid was present in $B$. perennis and $C$. intybus as we detected, but not in S. nigra and T. officinale.

Together with the other bioactive properties of phenolic acids, chlorogenic and ferulic acids are also characterized by working as antidiabetic agents (Kumar and Goel, 2019). Ferulic acid also counteracts the enzymes that catalyze the production of free radicals, while it enhances enzymes with free radical scavenging activity (Ou and Kwok, 2004). Our results showed the potentiality of 11 flowers (A. ursinum, B. perennis, $C$. intybus, E. dens-canis, G. sylvaticum, M. aquatica, $R$. canina, S. nigra, T. officinale, T. majus and $V$. odorata) with a very high amount of cinnamic acids that can be further evaluated for therapeutic application.

\section{Vitamin C content}

Vitamin C (Table 6) was detected in all the flowers, except for $A$. ursinum and $B$. officinalis, with values that ranged from $2.6 \mathrm{mg} \cdot 100 \mathrm{~g}^{-1}$ (M. aquatica) to $44.9 \mathrm{mg} \cdot 100 \mathrm{~g}^{-1}$ (P. veris). 
Table 6. Vitamin $\mathrm{C}$ content $\left(\mathrm{mg} \cdot 100 \mathrm{~g}^{-1}\right)$ in the flowers of the 26 studied species.

\begin{tabular}{lc}
\hline Species & Vitamin C \\
\hline Allium ursinum & $0.0-$ \\
Bellis perennis & $4.4 \mathrm{fi}$ \\
Centaurea cyanus & $3.3 \mathrm{gi}$ \\
Cichorium intybus & $4.0 \mathrm{gi}$ \\
Dianthus carthusianorum & $5.5 \mathrm{di}$ \\
Dianthus pavonius & $16.4 \mathrm{bc}$ \\
Erythronium dens-canis & $6.7 \mathrm{ch}$ \\
Geranium sylvaticum & $7.9 \mathrm{bg}$ \\
Lavandula angustifolia & $2.8 \mathrm{hi}$ \\
Leucanthemum vulgare & $5.9 \mathrm{di}$ \\
Mentha aquatica & $2.6 \mathrm{i}$ \\
Paeonia officinalis & $11.3 \mathrm{be}$ \\
Primula veris & $44.9 \mathrm{a}$ \\
Primula vulgaris & $3.8 \mathrm{gi}$ \\
Robinia pseudoacacia & $4.0 \mathrm{gi}$ \\
Rosa canina & $12.3 \mathrm{bd}$ \\
Rosa pendulina & $7.2 \mathrm{bg}$ \\
Salvia pratensis & $4.0 \mathrm{gi}$ \\
Sambucus nigra & $11.0 \mathrm{bf}$ \\
Taraxacum officinale & $3.5 \mathrm{gi}$ \\
Trifolium alpinum & $15.5 \mathrm{bc}$ \\
Viola odorata & $4.6 \mathrm{ei}$ \\
Borago officinalis & $0.0-$ \\
Calendula officinalis & $11.8 \mathrm{bd}$ \\
Tagetes patula & $7.2 \mathrm{bg}$ \\
Tropaeolum majus & $17.7 \mathrm{~b}$ \\
\hline Diffent lowerse &
\end{tabular}

Different lower case letters in a column indicate significant differences between species according to Tukey's post-hoc test $(p<0.05)$. Data are means of three biological replicates.

-, compound not detected.

${ }^{\S}$ Flowers sampled from cultivated plants.

Most of the flowers had a content of vitamin $\mathrm{C}$ up to $8 \mathrm{mg} \cdot 100 \mathrm{~g}^{-1}$, whereas eight species were significantly higher (D. pavonius, $P$. officinalis, $P$. veris, $R$. canina, $S$. nigra. T. alpinum, $C$. officinalis and T. majus), with $P$. veris having at least a three-fold higher concentration. Tropaeolum majus has one of the highest values, indeed a previous report indicated that this species can contain high quantities of vitamin $\mathrm{C}$, up to $71.5 \mathrm{mg} \cdot 100 \mathrm{~g}^{-1}$ (Lim, 2014b).

Vitamin $\mathrm{C}$ is one of the plant food components which contribute to lower the risk of cancer, chronic and cardiovascular diseases and premature mortality, together with antioxidants and other compounds (Barros et al., 2011; Aune, 2019). Moreover, vitamin C is essential as an enzymatic cofactor and in response to environmental stimuli. European Food Safety Authority established a Population Reference Intake of 95-110 mg per day for vitamin C (Fenech et al., 2019), easily satisfied by kiwifruit, which has an average content of vitamin $\mathrm{C}$ of $93 \mathrm{mg} \cdot 100 \mathrm{~g}^{-1} \mathrm{FW}$. In oranges the content is about $53 \mathrm{mg} \cdot 100 \mathrm{~g}^{-1} \mathrm{FW}$ and in apple $5 \mathrm{mg} \cdot 100 \mathrm{~g}^{-1} \mathrm{FW}$ (Cruz-Rus et al., 2012). Thus, most of the flowers have an interesting concentration of vitamin C, comparable to apples, and $P$. veris appears of particular interest as a supplement of vitamin $\mathrm{C}$ in the diet.

\section{Correlation among variables and species clustering}

The correlation analysis (Table 7) highlighted that the TPC of the 26 edible flowers was positively correlated with the antioxidant activity measured with the three assays (FRAP, DPPH and ABTS). These three methods of analysis also positively correlated with each other, confirming previous results on the positive link between TPC and antioxidant activity in edible flowers ( $\mathrm{Ji}$ et al., 2012; Kaisoon et al., 2012; Xiong et al., 2014; Lu et al., 2016; Petrova et al., 2016). The abovementioned parameters also correlated with the content of flavonols, ellagic acid, both catechins and vitamin C, but they did not correlate with the content of the four cinnamic acids and ellagic acid, probably being the reason for the different ranking of the species evaluated through RACI and chromatographic analysis.

The hierarchical cluster analysis performed on TPC and antioxidant activity data identified five main groups (Figure 3), reflecting the ranking of the 26 species based on RACI (Figure 1). A first group (A) is composed of $P$. officinalis and $R$. pendulina, characterized by the highest values in all parameters (TPC, FRAP, DPPH, ABTS). Another group (B) consists of $D$. carthusianorum, $M$. aquatica, $P$. veris, G. sylvaticum and $R$. canina, with very high values except for DPPH. The third group (C) is characterized by low values for every analysis and includes 11 species, from E. dens-canis to T. patula. Then, in the fourth group (D), there are the species with the lowest values, namely $B$. officinalis, $T$. officinale, C. officinalis, R. pseudoacacia and A. ursinum. Cichorium intybus, $P$. vulgaris and $D$. pavonius belong to the fifth group (E) with intermediate values between groups (B) and (C).

The results of the cluster analysis performed on phenolic profiles and vitamin C (Figure 4) show that four species should be considered not related to the others due to their peculiar characteristics ( $P$. officinalis $-\mathrm{A}, L$. angustifolia - G, R. pendulina- $\mathrm{H}$, and D. pavonius - I). Again, five groups formed, but the species differed from the previous cluster. The group with $R$. pseudoacacia and T. majus (B) has in common high values of quercitrin and ellagic acid, and a few other compounds were present. Species of the second group (C), from $B$. officinalis to $P$. vulgaris, shared low amounts of ellagic acid and epicatechin and have a few other compounds. Chlorogenic acid and quercetin are the major contributors of the third group (D) (from E. dens-canis to $R$. canina), while a miscellaneous few compounds are present in the fourth group (E) composed of L. vulgare, A. ursinum and D. carthusianorum. Finally, B. perennis and $C$. intybus belong to the fifth group (F), with high concentrations of epicatechin and coumaric acid.

A limited number of species resulted in the same groups in both dendrograms, namely: (i) T. alpinum, 


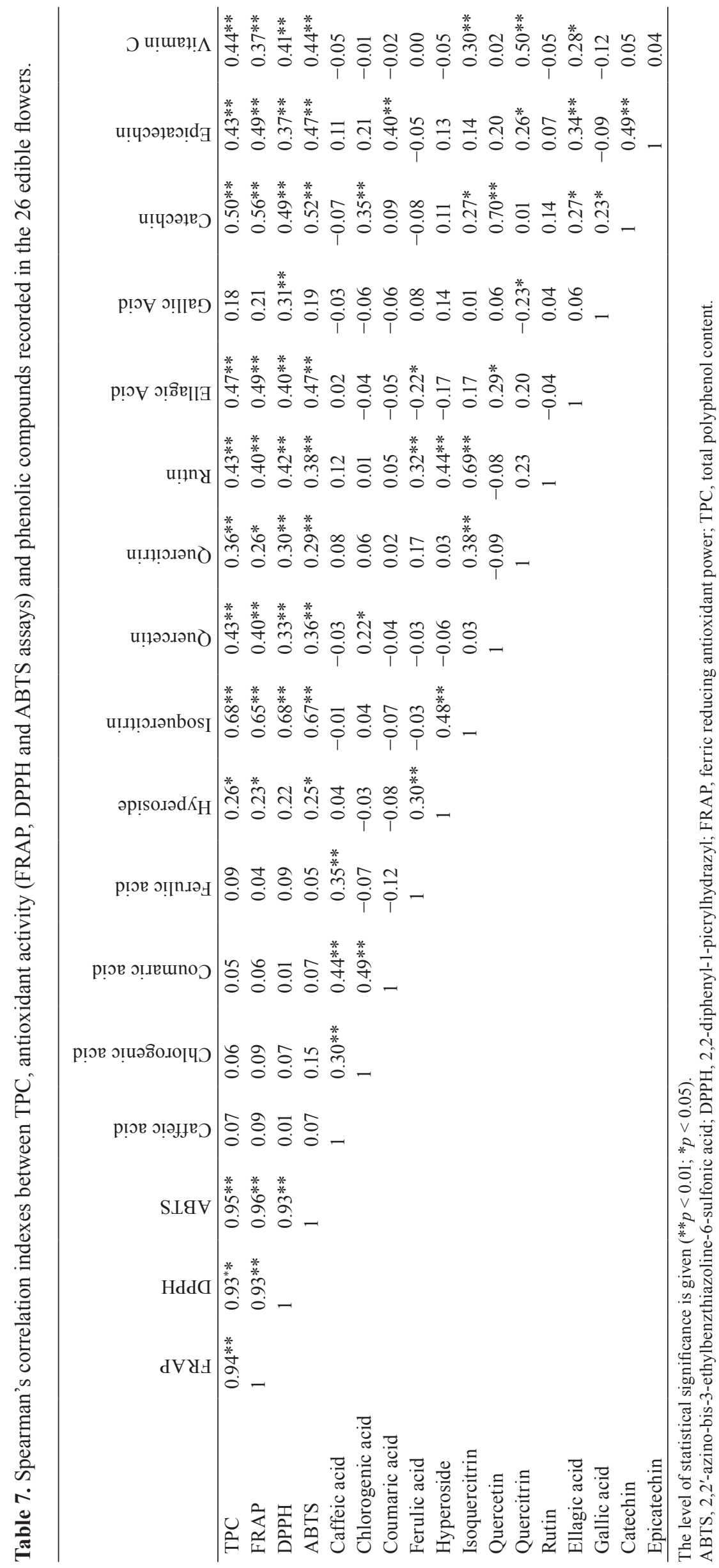




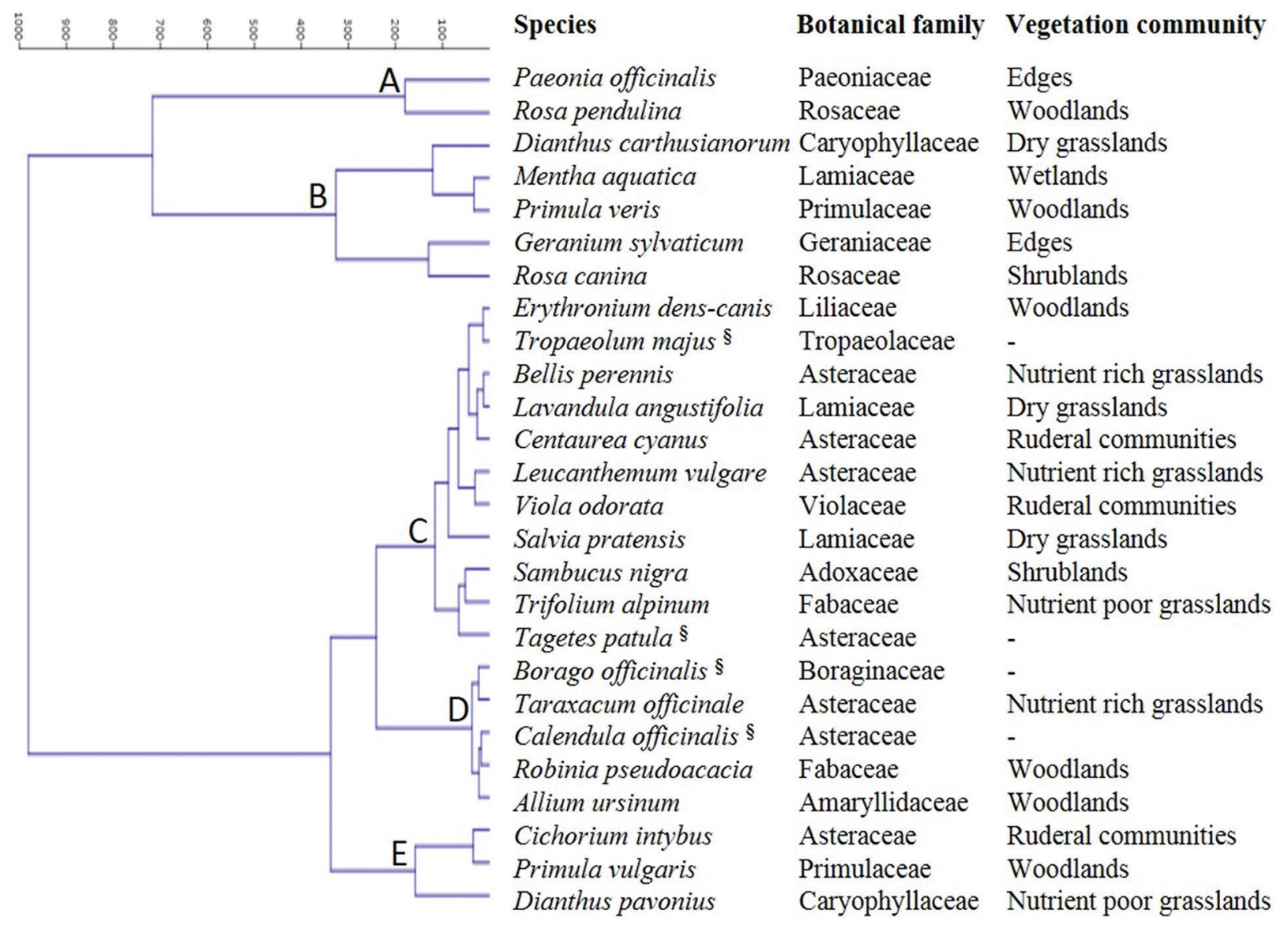

Figure 3. Hierarchical cluster analysis of the selected species according to their TPC and antioxidant activity (FRAP, $\mathrm{DPPH}$ and ABTS). The respective botanical family and vegetation community is provided for every species. ${ }^{\S} \mathrm{Flowers}$ sampled from cultivated plants. ABTS, 2,2'-azino-bis-3-ethylbenzthiazoline-6-sulfonic acid; DPPH, 2,2-diphenyl-1picrylhydrazyl; FRAP, ferric reducing antioxidant power; TPC, total polyphenol content.

S. pratensis, S. nigra, V. odorata, C. cyanus and $T$. patula; (ii) B. officinalis and C. officinalis; and (iii) $G$. sylvaticum, $M$. aquatica and $R$. canina. Interestingly, three couples of species belonging to the same genera showed significant differences both in their TPC and antioxidant activity and in their polyphenol profile and vitamin C content, as occurred in Dianthus, Primula and Rosa, therefore resulting separated in both dendrograms. The studied wild species derived from a wide variety of habitats and vegetation communities, namely seminatural pastures and meadows, woodlands, shrublands, wetlands and agricultural fallows, resulting from the complex interactions among heterogeneous ecological, topographic and management conditions (Aeschimann et al., 2013; Mondino, 2007). However, generally there was no clear distinction among groups neither in terms of botanical family, vegetation community, soil type nor bedrock type. Thus, the chemical composition of the selected species appeared more species-dependent rather than taxonomic- or habitat-dependent.

\section{CONCLUSIONS}

This investigation on 22 wild edible flowers compared with four cultivated plants showed wide variability in their phenolic and vitamin $\mathrm{C}$ content, as well as in their antioxidant activity, disclosing valuable sources of bioactive compounds. Generally, these traits appeared more species-dependent rather than taxonomic- or habitat-dependent. However, it has to be considered that the phytochemical profile of flowers and their bioactive compounds content are susceptible to variation, depending also on environmental conditions and stresses. The results showed that flowers of Dianthus pavonius and Rosa pendulina had the highest concentrations of polyphenols, displaying also the highest antioxidant activity, together with Geranium sylvaticum, Paeonia officinalis and Rosa canina. Each studied species was characterized by a peculiar phenolic profile and in most of the flowers, vitamin $\mathrm{C}$ has been identified, deserving further investigations, for instance, for the development of new food supplements or additives. Wild edible flowers outperformed three of the cultivated species (Borago officinalis, Calendula officinalis and Tagetes patula) in most of the analysis, while Tropaeolum majus had comparable results. Environmental stresses during plant growth may contribute to the high accumulation of bioactive molecules. The use of wild plants may have a positive impact on the local economy, because the environmental and economic costs of emerging produce 


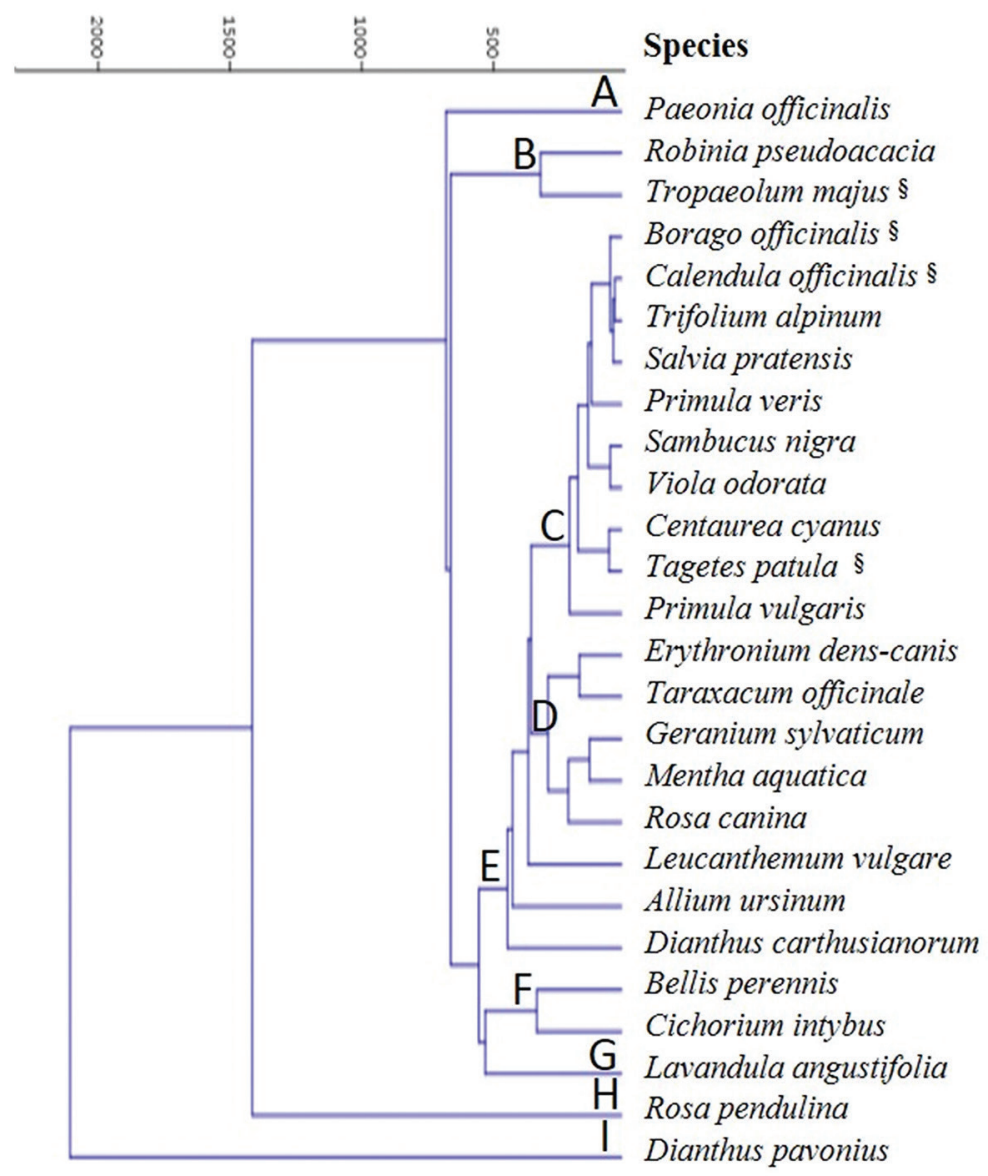

Botanical family Vegetation community

$\begin{array}{ll}\text { Paeoniaceae } & \text { Edges } \\ \text { Fabaceae } & \text { Woodlands } \\ \text { Tropaeolaceae } & - \\ \text { Boraginaceae } & - \\ \text { Asteraceae } & - \\ \text { Fabaceae } & \text { Nutrient poor grasslands } \\ \text { Lamiaceae } & \text { Dry grasslands } \\ \text { Primulaceae } & \text { Woodlands } \\ \text { Adoxaceae } & \text { Shrublands } \\ \text { Violaceae } & \text { Ruderal communities } \\ \text { Asteraceae } & \text { Ruderal communities } \\ \text { Asteraceae } & - \\ \text { Primulaceae } & \text { Woodlands } \\ \text { Liliaceae } & \text { Woodlands } \\ \text { Asteraceae } & \text { Nutrient rich grasslands } \\ \text { Geraniaceae } & \text { Edges } \\ \text { Lamiaceae } & \text { Wetlands } \\ \text { Rosaceae } & \text { Shrublands } \\ \text { Asteraceae } & \text { Nutrient rich grasslands } \\ \text { Amaryllidaceae } & \text { Woodlands } \\ \text { Caryophyllaceae } & \text { Dry grasslands } \\ \text { Asteraceae } & \text { Nutrient rich grasslands } \\ \text { Asteraceae } & \text { Ruderal communities } \\ \text { Lamiaceae } & \text { Dry grasslands } \\ \text { Rosaceae } & \text { Woodlands } \\ \text { Caryophyllaceae } & \text { Nutrient poor grasslands }\end{array}$

Figure 4. Hierarchical cluster analysis of the selected species according to their polyphenolic profile and vitamin $\mathrm{C}$ content. The respective botanical family and vegetation community is provided for every species. ${ }^{\S}$ Flowers sampled from cultivated plants.

with edible flowers (Falla et al., 2020; Fernandes et al., 2020) can be reduced, exploiting local resources. The valorization of quality and diversification of production can lead to higher revenue for growers, farmers or small enterprises (Takahashi et al., 2020). In order to support the consumption of edible flowers, it is of high importance in the future to evaluate and assess their sensory characteristics and postharvest performances. Furthermore, optimized cultivation protocols could standardize the produce. In this context, since lesser amount of flowers than vegetables and fruits is eaten, the application of intentional moderate stresses could foster the production of bioactive molecules (Caser et al., 2019). This will lead to increase and maintain across time the content of bioactive compounds, obtaining standard products that confer not only aesthetic value to the food, but also nutraceutical properties, to be accurately integrated into a healthy diet.

\section{ACKNOWLEDGMENTS}

The authors thank Regione Piemonte (Italy) for granting the sampling of flowers of the protected species Paeonia officinalis L. They also thank Eric Mozzanini and graduate students Sophie Ghirardi and Niccolò Leonardi for their contribution in the collection and analysis of plant material.

\section{FUNDING}

This research was funded by the program Interreg V-A Francia Italia Alcotra (Grant No. 1139 "ANTEA - Attività innovative per lo sviluppo della filiera transfrontaliera del fiore edule").

\section{AUTHOR CONTRIBUTIONS}

VS and ML were responsible for conceptualization; $\mathrm{SD}$ and $\mathrm{MC}$ conducted the investigation. SD, MC and DD performed data curation. SD, MC, SRE, ML and DD took care of formal analysis. VS was in charge of supervision. SD and $\mathrm{MC}$ were responsible for writing the original draft. SD, MC, DD, SRE, ML and VS undertook writing of the review edition. All authors contributed to manuscript revision, and read and approved the submitted version.

\section{CONFLICT OF INTEREST}

Authors declare no conflict of interest. 


\section{REFERENCES}

Abbet, C., Mayor, R., Roguet, D., Spichiger, R., Hamburger, M., And Potterat, O. (2014). Ethnobotanical survey on wild alpine food plants in Lower and Central Valais (Switzerland). Journal of Ethnopharmacology, 151(1), 624-634, doi: 10.1016/j. jep.2013.11.022.

Aeschimann, D., Lauber, K., Martin Moser, D., And Theurillat, J. P. (2004). Flora alpina. Bologna, Italia: Zanichelli.

Aeschimann, D., Rasolofo, N., and Theurillat, J. P. (2013). Analyse de la Flore des Alpes. 5: Milieux et Phytosociologie. Candollea, 68(1), 5-27, doi: 10.15553/c2013v681a1.

Agelet, A., And Vallès, J. (2001). Studies on pharmaceutical ethnobotany in the region of Pallars (Pyrenees, Catalonia, Iberian Peninsula). Part I. General results and new or very rare medicinal plants. Journal of Ethnopharmacology, 77(1), 57-70, doi: 10.1016/S0378-8741(01)00262-8.

Akula, R., and Ravishankar, G. A. (2011). Influence of abiotic stress signals on secondary metabolites in plants. Plant Signaling and Behavior, 6(11), 17201731, doi: 10.4161/PSB.6.11.17613.

Alvarado, A. M. (2018). Peppermint: The facts behind the aroma and flavor. In Martínez, A. C. and García, V. M. R. (Eds), Essential oils production, applications and health benefits (pp. 261-272). Nova Science Publishers, Inc.

Ananingsih, V. K., Sharma, A., And Zhou, W. (2013). Green tea catechins during food processing and storage: A review on stability and detection. Food Research International, 50(2), 469-479, doi: 10.1016/j.foodres.2011.03.004.

Apel, L., Kammerer, D. R., Stintzing, F. C., And Spring, O. (2017). Comparative metabolite profiling of triterpenoid saponins and flavonoids in flower color mutations of Primula veris L. International Journal of Molecular Sciences, 18(1), 153, doi: 10.3390/ ijms18010153.

Ashraf, M. A., Iqbal, M., Rasheed, R., Hussain, I., Riaz, M., AND ARIF, M. S. (2018). Environmental stress and secondary metabolites in plants. In Ahmad, P., Ahanger, M. A., Singh, V. P., Tripathi, D. K., Alam, P., and Alyemeni, M. N. (Eds), Plant metabolites and regulation under environmental stress (pp. 153-167). Elsevier Inc.

Aune, D. (2019). Plant foods, antioxidant biomarkers, and the risk of cardiovascular disease, cancer, and mortality: A review of the evidence. Advances in Nutrition, 10, S404-S421, doi: 10.1093/advances/ nmz042.

Barros, L., Carvalho, A. M., and Ferreira, I. C. (2011). Exotic fruits as a source of important phytochemicals: Improving the traditional use of Rosa canina fruits in Portugal. Food Research International, 44(7), 2233-2236, doi: 10.1016/j.foodres.2010.10.005.
Bartolucci, F., Peruzzi, L., Galasso, G., Albano, A., Alessandrini, A. N. M. G., Ardenghi, N. M. G., Astuti, G., Bacchetta, G., Ballelli, S., Banfi, E., Barberis, G., Bernardo, L., Bouvet, D., Bovio, M., Cecchi, L., Di Pietro, R., Domina, G., Fascetti, S., Fenu, G., Festi, F., Foggi, B., Gallo, L., Gottschlich, G., Gubellini, L., Iamonico, D., Iberite, M., Jiménez-Mejías, P., Lattanzi, E., Marchetti, D., Martinetto, E., Masin, R. R., Medagli, P., Passalacqua, N. G., Peccenini, S., Pennesi, R., Pierini, B., Poldini, L., Prosser, F., Raimondo, F. M., Roma-Marzio, F., Rosati, L., Santangelo, A., Scoppola, A., Scortegagna, S., Selvaggi, A., Selvi, F., Soldano, A., Stinca, A., Wagensommer, R. P., Wilhalm, T., and Conti, F. (2018). An updated checklist of the vascular flora native to Italy. Plant Biosystems - An International Journal Dealing with All Aspects of Plant Biology, 152(2), 179-303, doi: 10.1080/11263504.2017.1419996.

Benzie, I. F., and Strain, J. J. (1998). Ferric reducing/ antioxidant power assay: Direct measure of total antioxidant activity of biological fluids and modified version for simultaneous measurement of total antioxidant power and ascorbic acid concentration. Methods in Enzymology, 299, 15-27, doi: 10.1016/ S0076-6879(99)99005-5.

Brito, C., Bertotti, T., Primitivo, M. J., Neves, M., Pires, C. L., Cruz, P. F., Martins, P. A. T., Rodrigues, A. C., Moreno, M. J., Brito, R. M. M., Campos, M. J., Vaz, D. C., Pessoa, M. F., Lidon, F., Reboredo, F., And Ribeiro, V. S. (2021). Corema album spp: Edible wild crowberries with a high content in minerals and organic acids. Food Chemistry, 345, 128732, doi: 10.1016/j.foodchem.2020.128732.

Bulgari, R., Baldi, A., Ferrante, A., And Lenzi, A. (2017). Yield and quality of basil, Swiss chard, and rocket microgreens grown in a hydroponic system. New Zealand Journal of Crop and Horticultural Science, 45(2), 119-129, doi: 10.1080/01140671.2016.1259642.

Butnariu, M., And Coradini, C. Z. (2012). Evaluation of biologically active compounds from Calendula officinalis flowers using spectrophotometry. Chemistry Central Journal, 6(1), 35, doi: 10.1186/1752-153X-6-35.

Caritá, A. C., Fonseca-Santos, B., Shultz, J. D., Michniak-Kohn, B., Chorilli, M., and Leonardi, G. R. (2020). Vitamin C: One compound, several uses. Advances for delivery, efficiency and stability. Nanomedicine: Nanotechnology, Biology and Medicine, 24, 102117, doi: 10.1016/j.nano.2019.102117.

Caser, M., Demasi, S., Victorino, Í. M. M., Donno, D., Faccio, A., Lumini, E., Bianciotto, V., and Scariot, V. (2019). Arbuscular mycorrhizal fungi modulate the crop performance and metabolic profile of saffron in soilless cultivation. Agronomy, 9(5), 232, doi: 10.3390/agronomy9050232.

Ceccanti, C., Landi, M., Benvenuti, S., Pardossi, A., AND GuidI, L. (2018). Mediterranean wild edible 
plants: Weeds or "new functional crops"? Molecules, 23(9), 2299, doi: 10.3390/molecules23092299.

Chensom, S., Okumura, H., and Mishima, T. (2019). Primary screening of antioxidant activity, total polyphenol content, carotenoid content, and nutritional composition of 13 edible flowers from Japan. Preventive Nutrition and Food Science, 24(2), 171-178, doi: 10.3746/pnf.2019.24.2.171.

Cruz-Rus, E., Amaya, I., and Valpuesta, V. (2012). The challenge of increasing vitamin $\mathrm{C}$ content in plant foods. Biotechnology Journal, 7(9), 1110-1121, doi: 10.1002/biot.201200041.

Cutler, S. R., Rodriguez, P. L., Finkelstein, R. R., And Abrams, S. R. (2010). Abscisic acid: Emergence of a core signaling network. Annual Review of Plant Biology, 61, 651-679, doi: 10.1146/annurevarplant-042809-112122.

D’angiolillo, F., Mammano, M. M., and Fascella, G. (2018). Pigments, polyphenols and antioxidant activity of leaf extracts from four wild rose species grown in Sicily. Notulae Botanicae Horti Agrobotanici Cluj-Napoca, 46(2), 402-409, doi: $10.15835 /$ nbha46211061.

Del Rio, D., Rodriguez-Mateos, A., Spencer, J. P., Tognolini, M., Borges, G., And Crozier, A. (2013). Dietary (poly)phenolics in human health: Structures, bioavailability, and evidence of protective effects against chronic diseases. Antioxidants and Redox Signaling, 18, 1818-1892, doi: 10.1089/ars.2012.4581.

Demasi, S., Caser, M., Lonati, M., Cioni, P. L., Pistelli, L., Najar, B., And Scariot, V. (2018). Latitude and altitude influence secondary metabolite production in peripheral alpine populations of the mediterranean species Lavandula angustifolia Mill. Frontiers in Plant Science, 9, 983, doi: 10.3389/fpls.2018.00983.

Demasi, S., Falla, N. M., Caser, M., and Scariot, V. (2020). Postharvest aptitude of Begonia semperflorens and Viola cornuta edible flowers. Advances in Horticultural Science, 34(1S), 13-20, doi: 10.13128/ahsc7444.

Donno, D., Mellano, M. G., Riondato, I., De Biaggi, M., Andriamaniraka, H., Gamba, G., and Beccaro, G. L. (2019). Traditional and unconventional dried fruit snacks as a source of health-promoting compounds. Antioxidants, 8(9), 396, doi: 10.3390/antiox8090396.

Dudonné, S., Vitrac, X., Coutiére, P., Woillez, M., And Mérillon, J. M. (2009). Comparative study of antioxidant properties and total phenolic content of 30 plant extracts of industrial interest using DPPH, ABTS, FRAP, SOD, and ORAC assays. Journal of Agricultural and Food Chemistry, 57(5), 1768-1774, doi: 10.1021/jf803011r.

Durazzo, A., Lucarini, M., Souto, E. B., Cicala, C., Cainzzo, E., Izzo, A. A., Novellino, E., Santini, A. (2019). Polyphenols: A concise overview on the chemistry, occurrence, and human health. Phytotherapy Research, 33(9), 2221-2243, doi: $10.1002 /$ ptr.6419.
Egebjerg, M. M., Olesen, P. T., Eriksen, F. D., RavnHaren, G., Bredsdorff, L., And Pilegaard, K. (2018). Are wild and cultivated flowers served in restaurants or sold by local producers in Denmark safe for the consumer? Food and Chemical Toxicology, 120, 129-142, doi: 10.1016/j.fct.2018.07.007.

Falla, N. M., Contu, S., Demasi, S., Caser, M., And ScAriot, V. (2020). Environmental impact of edible flower production: A case study. Agronomy, 10(4), 1-17, doi: 10.3390/agronomy10040579.

FAn, J., Zhu, W., KANG, H., MA, H., AND TAO, G. (2012). Flavonoid constituents and antioxidant capacity in flowers of different Zhongyuan tree penoy cultivars. Journal of Functional Foods, 4(1), 147-157, doi: 10.1016/j.jff.2011.09.006.

Fascella, G., D’angiolillo, F., Mammano, M. M., Amenta, M., Romeo, F. V., Rapisarda, P., AND BAllistreri, G. (2019). Bioactive compounds and antioxidant activity of four rose hip species from spontaneous Sicilian flora. Food Chemistry, 289, 56-64, doi: 10.1016/j.foodchem.2019.02.127.

Fenech, M., Amaya, I., Valpuesta, V., and Botella, M. A. (2019). Vitamin C content in fruits: Biosynthesis and regulation. Frontiers in Plant Science, 9, 2006, doi: 10.3389/fpls.2018.02006.

Fernandes, L., Casal, S., Pereira, J. A., Saraiva, J. A., and Ramalhosa, E. (2017). Edible flowers: A review of the nutritional, antioxidant, antimicrobial properties and effects on human health. Journal of Food Composition and Analysis, 60, 38-50, doi: 10.1016/j.jfca.2017.03.017.

Fernandes, L., Casal, S., Pereira, J. A., Saraiva, J. A., and Ramalhosa, E. (2020). An overview on the market of edible flowers. Food Reviews International, 36(3), 258-275, doi: 10.1080/87559129.2019.1639727.

Friedman, H., Agami, O., Vinokur, Y., Droby, S., Cohen, L., Refaeli, G., Resnick, N. and Umiel, N. (2010). Characterization of yield, sensitivity to Botrytis cinerea and antioxidant content of several rose species suitable for edible flowers. Scientia Horticulturae, 123(3), 395-401, doi: 10.1016/j. scienta.2009.09.019.

Gamsjaeger, S., Baranska, M., Schulz, H., Heiselmayer, P., AND Musso, M. (2011). Discrimination of carotenoid and flavonoid content in petals of pansy cultivars (Viola $\times$ wittrockiana) by FT-Raman spectroscopy. Journal of Raman Spectroscopy, 42(6), 1240-1247, doi: 10.1002/jrs.2860.

Garzón, G. A., and Wrolstad, R. E. (2009). Major anthocyanins and antioxidant activity of Nasturtium flowers (Tropaeolum majus). Food Chemistry, 114(1), 44-49, doi: 10.1016/j.foodchem.2008.09.013.

Gonçalves, A. F. K., Friedrich, R. B., Boligon, A. A., Piana, M., Beck, R. C. R., and Athayde, M. L. (2012). Anti-oxidant capacity, total phenolic contents and HPLC determination of rutin in Viola tricolor (L) flowers. Free Radicals and Antioxidants, 2(4), 32-37, doi: 10.5530/ax.2012.4.6. 
Grzeszczuk, M., Stefaniak, A., and Pachlowska, A. (2016). Biological value of various edible flower species. Acta Scientiarum Polonorum, Hortorum Cultus, 15(2), 109-119.

Gupta, M., And Singh, S. (2010). Borago officinalis Linn. an important medicinal plant of Mediterranean region: Review. International Journal of Pharmaceutical Sciences Review and Research, 5(1), 27-34.

Hammer, Ø., Harper, D. A., and Ryan, P. D. (2001). PAST: Paleontological statistics software package for education and data analysis. Palaeontologia Electronica, 4(1), 9.

Jarić, S., Mačukanović-Jocić, M., Duurdjević, L., Mitrović, M., Kostić, O., Karadžić, B., And Pavlović, P. (2015). An ethnobotanical survey of traditionally used plants on Suva planina mountain (southeastern Serbia). Journal of Ethnopharmacology, 175, 93-108, doi: 10.1016/j.jep.2015.09.002.

Ji, H. F., Du, A. L., Zhang, L. W., Xu, C. Y., Yang, M. D., AND Li, F. F. (2012). Effects of drying methods on antioxidant properties in Robinia pseudoacacia L. flowers. Journal of Medicinal Plants Research, 6(16), 3233-3239, doi: 10.5897/JMPR12.107.

Kaisoon, O., KonczaK, I., And Siriamornpun, S. (2012). Potential health enhancing properties of edible flowers from Thailand. Food Research International, 46(2), 563-571, doi: 10.1016/j.foodres.2011.06.016.

Kalemba-Drożdż, M., AND Cierniak, A. (2019). Antioxidant and genoprotective properties of extracts from edible flowers. Journal of Food and Nutrition Research, 58(1), 42-50.

Kim, H. K., Jeong, T. S., Lee, M. K., Park, Y. B., And Chol, M. S. (2003). Lipid-lowering efficacy of hesperetin metabolites in high-cholesterol fed rats. Clinica Chimica Acta, 327(1-2), 129-137, doi: 10.1016/S0009-8981(02)00344-3.

Kucekova, Z., Mlcek, J., Humpolicek, P., and Rop, O. (2013). Edible flowers - Antioxidant activity and impact on cell viability. Open Life Sciences, 8(10), 1023-1031, doi: 10.2478/s11535-013-0212-y.

Kumar, N., And Goel, N. (2019). Phenolic acids: Natural versatile molecules with promising therapeutic applications. Biotechnology Reports, 24, e00370, doi: 10.1016/j.btre.2019.e00370.

Kumar, N., Bhandari, P., Singh, B., and Bari, S. S. (2009). Antioxidant activity and ultra-performance LC-electrospray ionization-quadrupole timeof-flight mass spectrometry for phenolics-based fingerprinting of Rose species: Rosa damascena, Rosa bourboniana and Rosa brunonii. Food and Chemical Toxicology, 47(2), 361-367, doi: 10.1016/j. fct.2008.11.036.

LANDETE, J. M. (2011). Ellagitannins, ellagic acid and their derived metabolites: A review about source, metabolism, functions and health. Food Research International, 44(5), 1150-1160, doi: 10.1016/j. foodres.2011.04.027.
Lapuente, M., Estruch, R., Shahbaz, M., and Casas, R. (2019). Relation of fruits and vegetables with major cardiometabolic risk factors, markers of oxidation, and inflammation. Nutrients, 11(10), 2381, doi: 10.3390/nu11102381.

Li, A. N., Li, S., Li, H. B., Xu, D. P., Xu, X. R., And Chen, F. (2014). Total phenolic contents and antioxidant capacities of 51 edible and wild flowers. Journal of Functional Foods, 6(1), 319-330, doi: 10.1016/j. jff.2013.10.022.

Li, F., Li, S., Li, H. B., Deng, G. F., Ling, W. H., Wu, S., Xu, X. R. And Chen, F. (2013). Antiproliferative activity of peels, pulps and seeds of 61 fruits. Journal of Functional Foods, 5(3), 1298-1309, doi: 10.1016/j. jff.2013.04.016.

Lim, T. K. (2014a). Edible medicinal and non-medicinal plants. (Vol. 7), Flowers. Dordrecht, Netherlands: Springer Science+Business Media, doi: 10.1007/97894-007-7395-0.

Lim, T. K. (2014b). Edible medicinal and non-medicinal plants. (Vol. 8), Flowers. Dordrecht, Netherlands: Springer Science+Business Media, doi: 10.1007/97894-017-8748-2.

Loizzo, M. R., Pugliese, A., Bonesi, M., Tenuta, M. C., Menichini, F., XiaO, J., And Tundis, R. (2016). Edible flowers: A rich source of phytochemicals with antioxidant and hypoglycemic properties. Journal of Agricultural and Food Chemistry, 64(12), 2467 2474, doi: 10.1021/acs.jafc.5b03092.

López-García, J., Kuceková, Z., Humpolícek, P., Mlcek, J., AND SÁHA, P. (2013). Polyphenolic extracts of edible flowers incorporated onto atelocollagen matrices and their effect on cell viability. Molecules, 18(11), 13435-13445, doi: 10.3390/molecules181113435.

Loreto, F., Dicke, M., Schnitzler, J. P., And Turlings, T. C.. (2014). Plant volatiles and the environment. Plant, Cell \& Environment, 37(8), 1905-1908.

Lu, B., Li, M., And Yin, R. (2016). Phytochemical content, health benefits, and toxicology of common edible flowers: A review (2000-2015). Critical Reviews in Food Science and Nutrition, 56, S130-S148, doi: 10.1080/10408398.2015.1078276.

Maleki, S. J., Crespo, J. F., and Cabanillas, B. (2019). Anti-inflammatory effects of flavonoids. Food Chemistry, 299, 125124, doi: 10.1016/j. foodchem.2019.125124.

MŁynarczyk, K., Walkowiak-Tomczak, D., and Łysiak, G. P. (2018). Bioactive properties of Sambucus nigra L. as a functional ingredient for food and pharmaceutical industry. Journal of Functional Foods, 40, 377-390, doi: 10.1016/j.jff.2017.11.025.

Moliner, C., Barros, L., Dias, M. I., Reigada, I., Ferreira, I. C., López, V., Langa, E., Rincón, C. G. (2019). Viola cornuta and Viola $\times$ wittrockiana: Phenolic compounds, antioxidant and neuroprotective activities on Caenorhabditis elegans. Journal of Food and Drug Analysis, 27(4), 849-859, doi: 10.1016/j.jfda.2019.05.005. 
Mondino, G. P. (2007). Flora e vegetazione del Piemonte. Regione Piemonte L'Artistica Editrice, Savigliano.

Montoro, P., Serreli, G., Gil, K. A., D’urso, G., Kowalczyk, A., and Tuberoso, C. I. G. (2020). Evaluation of bioactive compounds and antioxidant capacity of edible feijoa (Acca sellowiana (O. Berg) Burret) flower extracts. Journal of Food Science and Technology, 57, 2051-2060, doi: 10.1007/s13197020-04239-2.

Mulík, S., And Ozuna, C. (2020). Mexican edible flowers: Cultural background, traditional culinary uses, and potential health benefits. International Journal of Gastronomy and Food Science, 21, 100235, doi: 10.1016/j.ijgfs.2020.100235.

Najar, B., Demasi, S., Caser, M., Gaino, W., Cioni, P. L., Pistelli, L., and Scariot, V. (2019). Cultivation substrate composition influences morphology, volatilome and essential oil of Lavandula angustifolia Mill. Agronomy, 9(8), 411, doi: 10.3390/ agronomy9080411.

Nazaruk, J., And GudeJ, J. (2001). Qualitative and quantitative chromatographic investigation of flavonoids in Bellis perennis L. Acta Poloniae Pharmaceutica, 58(5), 401-404.

Nemati, Z., Komaki, A., Shahidi, S., and Sarihi, A. (2015). Effect of a hydroalcoholic extract of Rosa canina flowers on anxiety in rats. Neurophysiology, 47(2), 133-137, doi: 10.1007/ s11062-015-9509-y.

Ou, S., AND KwoK, K.-C. (2004). Ferulic acid: Pharmaceutical functions, preparation and applications in foods. Journal of the Science of Food and Agriculture, 84(11), 1261-1269, doi: 10.1002/ jsfa.1873.

Palma, L. (1964). Le piante medicinali d'Italia. Torino, Italy: Società Editrice Internazionale.

Pérez-Jiménez, J., Neveu, V., Vos, F., and Scalbert, A. (2010). Systematic analysis of the content of 502 polyphenols in 452 foods and beverages: An application of the Phenol-Explorer database. Journal of Agricultural and Food Chemistry, 58(8), 49594969, doi: 10.1021/jf100128b.

Petrova, I., Petkova, N., and Ivanov, I. (2016). Five edible flowers - Valuable source of antioxidants in human nutrition. International Journal of Pharmacognosy and Phytochemical Research, 8(4), 604-610.

Piccolella, S., Crescente, G., Pacifico, F., and Pacifico, S. (2018). Wild aromatic plants bioactivity: A function of their (poly)phenol seasonality? A case study from Mediterranean area. Phytochemistry Reviews, 17(4), 785-799, doi: 10.1007/s11101-0189558-0.

Pignatti, S., La Rosa, M., and Guarino, R. (2017). Flora d'Italia. Edagricole-New Business Media. Retrieved from https://books.google.it/ books?id=nzkJfAEACAAJ.
Pires, T. C., Barros, L., Santos-Buelga, C., And Ferreira, I. C.. (2019). Edible flowers: Emerging components in the diet. Trends in Food Science \& Technology, 93, 244-258, doi: 10.1016/j. tifs.2019.09.020.

Prinsloo, G., Nogemane, N., and Street, R. (2018). The use of plants containing genotoxic carcinogens as foods and medicine. Food and Chemical Toxicology, 116, 27-39, doi: 10.1016/j.fct.2018.04.009.

Rachkeeree, A., Kantadoung, K., Suksathan, R., Puangrradab, R., Page, P. A., and Sommano, S. R. (2018). Nutritional compositions and phytochemical properties of the edible flowers from selected Zingiberaceae found in Thailand. Frontiers in Nutrition, 5, 3, doi: 10.3389/fnut.2018.00003.

Regione Autonoma Valle D'aosta (2018). Carta dei suoli della Valle d'Aosta 1:100.000. Geoportale Valle d'Aosta. Available at: https://mappe.regione.vda.it/ pub/geonavsct/?repertorio=SOIL_MAP

Regione Piemonte (2007). I.P.L.A., Istituto per le Piante da Legno e l'Ambiente, Carta dei suoli del Piemonte a scala 1:250.000. Selca, Firenze.

Rinninella, E., Cintoni, M., Raoul, P., Lopetuso, L. R., Scaldaferri, F., Pulcini, G., Miggiano, G.A.D., Gasbarrini, A., Mele, M. C. (2019). Food components and dietary habits: Keys for a healthy gut microbiota composition. Nutrients, 11(10), 2393, doi: 10.3390/nu11102393.

Rop, O., Mlcek, J., Jurikova, T., Neugebauerova, J., And Vabkova, J. (2012). Edible flowers - A new promising source of mineral elements in human nutrition. Molecules, 17(6), 6672-6683, doi: 10.3390/ molecules17066672.

Sánchez-Rangel, J. C., Benavides, J., Heredia, J. B., Cisneros-Zevallos, L., AND JaCOBo-Velázquez, D. A. (2013). The Folin-Ciocalteu assay revisited: Improvement of its specificity for total phenolic content determination. Analytical Methods, 5(21), 5990-5999, doi: 10.1039/c3ay41125g.

Sangwan, N. S., Faroogi, A. H. A., Shabih, F., And SAngwan, R. S. (2001). Regulation of essential oil production in plants. Plant Growth Regulation, 34(1), 3-21, doi: 10.1023/A:1013386921596.

Santos-Buelga, C., Gonzalez-Manzano, S., Dueñas, M., And Gonzalez-Paramas, A. M. (2012). Extraction and isolation of phenolic compounds. Methods in Molecular Biology, 864, 427-464, doi: 10.1007/9781-61779-624-1_17.

Scariot, V., Gaino, W., Demasi, S., Caser, M., And Ruffoni, B. (2018). Flowers for edible gardens: Combinations of species and colours for northwestern Italy. Acta Horticulturae, 1215, 363-368, doi: 10.17660/ActaHortic.2018.1215.67.

Shaheen, S., Ahmad, M., and Haroon, N. (2017). Edible wild plants: A solution to overcome food insecurity. In Edible wild plants: An alternative approach to food security (pp. 41-57). Cham, Switzerland: 
Springer International Publishing, doi: 10.1007/9783-319-63037-3 2.

Skowyra, M., Calvo, M. I., Gallego, M. G., Azman, N. A. M., And Almajano, M. P. (2014). Characterization of phytochemicals in petals of different colours from Viola $\times$ wittrockiana Gams. and their correlation with antioxidant activity. Journal of Agricultural Science, 6(9), 93-105, doi: 10.5539/jas.v6n9p93.

Skrajda-Brdak, M., Dąbrowski, G., and Konopka, I. (2020). Edible flowers, a source of valuable phytonutrients and their pro-healthy effects - A review. Trends in Food Science \& Technology, 103, 179-199, doi: 10.1016/j.tifs.2020.06.016.

Slinkard, K., And Singleton, V. L. (1977). Total phenol analysis: Automation and comparison with manual methods. American Journal of Enology and Viticulture, 28(1), 49-55.

Sobolewska, D., Podolak, I., And MakowsKa-Wąs, J. (2015). Allium ursinum: Botanical, phytochemical and pharmacological overview. Phytochemistry Reviews, 14(1), 81-97, doi: 10.1007/s11101-013-9334-0.

Street, R. A., Sidana, J., And Prinsloo, G. (2013). Cichorium intybus: Traditional uses, phytochemistry, pharmacology, and toxicology. Evidence-Based Complementary and Alternative Medicine, 2013, 579319, doi: 10.1155/2013/579319.

Sun, T., and Tanuminardjo, S. A. (2007). An integrated approach to evaluate food antioxidant capacity. Journal of Food Science, 72(9), R159-R165, doi: 10.1111/j.1750-3841.2007.00552.x.

Takahashi, J. A., Rezende, F. A. G. G., Moura, M. A. F., Dominguete, L. C. B., And SAnde, D. (2020). Edible flowers: Bioactive profile and its potential to be used in food development. Food Research International, 129, 108868, doi: 10.1016/j.foodres.2019.108868.

Tawaha, K., Alali, F. Q., Gharaibeh, M., Mohammad, M., and El-Elimat, T. (2007). Antioxidant activity and total phenolic content of selected Jordanian plant species. Food Chemistry, 104(4), 1372-1378, doi: 10.1016/j.foodchem.2007.01.064.

Tuttolomondo, T., Licata, M., Leto, C., Gargano, M. L., Venturella, G., and La Bella, S. (2014). Plant genetic resources and traditional knowledge on medicinal use of wild shrub and herbaceous plant species in the Etna Regional Park (Eastern Sicily, Italy). Journal of Ethnopharmacology, 155(2), 13621381, doi: 10.1016/j.jep.2014.07.043.

Vukics, V., Kery, A., and Guttman, A. (2008). Analysis of polar antioxidants in heartsease (Viola tricolor L.) and garden pansy (Viola $\times$ wittrockiana Gams.). Journal of Chromatographic Science, 46(9), 823-827, doi: 10.1093/chromsci/46.9.823.

Weixing, L., Shunbo, Y., Hui, C., Yanmin, H., Jun, T., and Chunhua, Z. (2017). Nutritional evaluation of Herbaceous peony (Paeonia lactiflora Pall.) petals. Emirates Journal of Food and Agriculture, 29(7), 518-531, doi: 10.9755/EJFA.2017-05-1061.

Wong, S. P., Leong, L. P., And Koh, J. H. W. (2006). Antioxidant activities of aqueous extracts of selected plants. Food Chemistry, 99(4), 775-783, doi: 10.1016/j.foodchem.2005.07.058.

Xiong, L., Yang, J., Jiang, Y., Lu, B., Hu, Y., Zhou, F., Mao, S. And Shen, C. (2014). Phenolic compounds and antioxidant capacities of 10 common edible flowers from China. Journal of Food Science, 79(4), C517-C525, doi: 10.1111/1750-3841.12404.

Zeng, Y., Deng, M., Lv, Z., And Peng, Y. (2014). Evaluation of antioxidant activities of extracts from 19 Chinese edible flowers. SpringerPlus, 3(1), 315, doi: 10.1186/2193-1801-3-315.

Zhao, L., Fan, H., Zhang, M., Chitrakar, B., BhANDARI, B., AND WANG, B. (2019). Edible flowers: Review of flower processing and extraction of bioactive compounds by novel technologies. Food Research International, 126, 108660, doi: 10.1016/j. foodres.2019.108660.

Zheng, J., Lu, B., And Xu, B. (2021). An update on the health benefits promoted by edible flowers and involved mechanisms. Food Chemistry, 340, 127940, doi: 10.1016/j.foodchem.2020.127940.

Zheng, J., Yu, X., Maninder, M., And Xu, B. (2018). Total phenolics and antioxidants profiles of commonly consumed edible flowers in China. International Journal of Food Properties, 21(1), 1524-1540, doi: 10.1080/10942912.2018.1494195.

Received: November 24, 2020; accepted: February 3, 2021. 


\section{APPENDIX}

\begin{tabular}{lccccccccccccccccccccccccccccc}
\hline Hyperoside & $\mathrm{b}$ & - & - & $\mathrm{bc}$ & $\mathrm{a}$ & - & $\mathrm{cd}$ & $\mathrm{e}$ & $\mathrm{bd}$ & - & - & - & $\mathrm{bd}$ & $\mathrm{cd}$ & - & $\mathrm{b}$ & $\mathrm{bd}$ & - & - & $\mathrm{e}$ & $\mathrm{d}$ & $\mathrm{bd}$ & - & - & - & - \\
Isoquercitrin & - & - & - & $\mathrm{c}$ & $\mathrm{b}$ & $\mathrm{a}$ & - & $\mathrm{c}$ & - & - & $\mathrm{c}$ & - & $\mathrm{c}$ & $\mathrm{b}$ & - & $\mathrm{b}$ & $\mathrm{b}$ & - & - & - & $\mathrm{c}$ & $\mathrm{c}$ & - & - & - & - \\
Quercetin & - & - & - & - & - & - & - & $\mathrm{a}$ & $\mathrm{a}$ & $\mathrm{a}$ & $\mathrm{a}$ & $\mathrm{a}$ & - & - & - & $\mathrm{a}$ & - & - & - & $\mathrm{b}$ & - & - & - & - & - & - \\
Quercitrin & $\mathrm{c}$ & - & $\mathrm{c}$ & - & $\mathrm{c}$ & $\mathrm{c}$ & $\mathrm{c}$ & $\mathrm{c}$ & - & - & - & $\mathrm{c}$ & $\mathrm{c}$ & $\mathrm{c}$ & $\mathrm{b}$ & $\mathrm{c}$ & $\mathrm{a}$ & - & $\mathrm{c}$ & - & $\mathrm{c}$ & $\mathrm{c}$ & - & $\mathrm{c}$ & - & $\mathrm{b}$ \\
Rutin & $\mathrm{b}$ & - & - & $\mathrm{b}$ & $\mathrm{b}$ & $\mathrm{b}$ & $\mathrm{c}$ & $\mathrm{b}$ & - & - & $\mathrm{b}$ & - & $\mathrm{b}$ & $\mathrm{a}$ & - & - & $\mathrm{b}$ & - & - & $\mathrm{c}$ & $\mathrm{c}$ & $\mathrm{b}$ & - & - & $\mathrm{c}$ & - \\
\hline
\end{tabular}

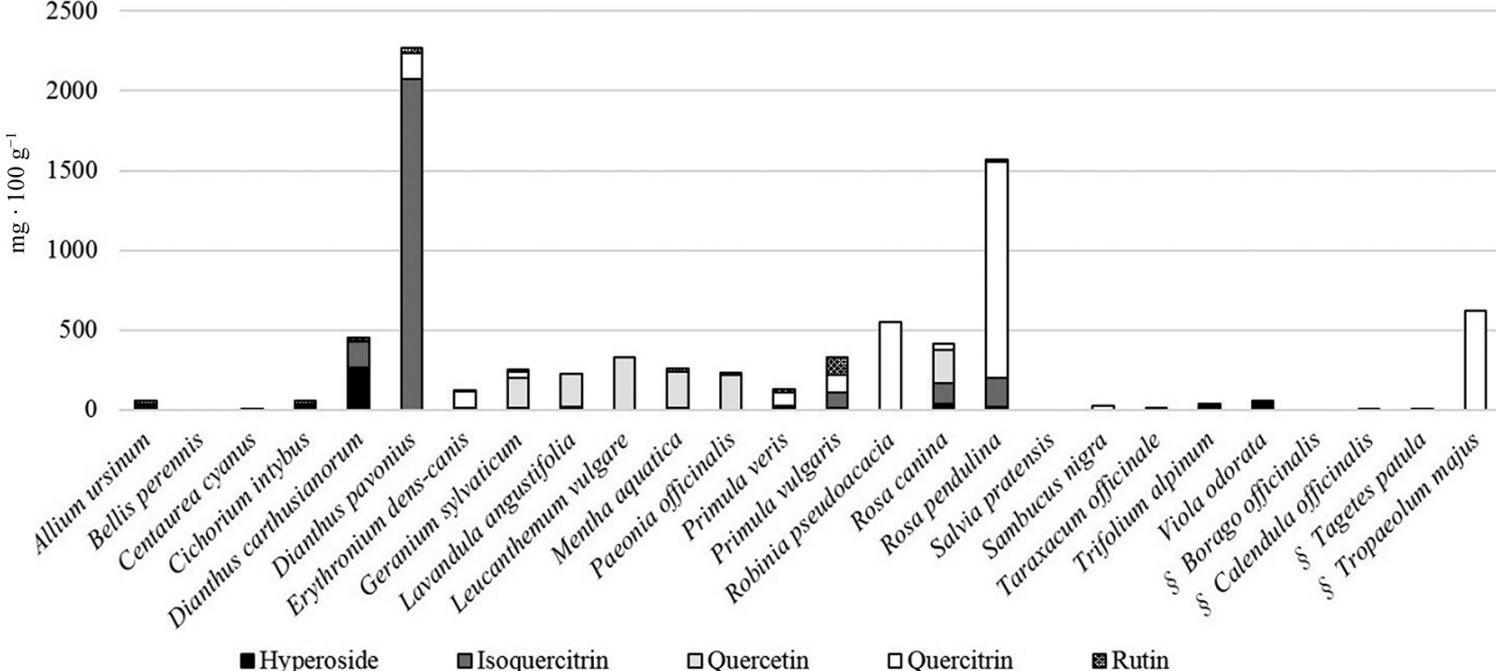

Figure A1. Flavonols (hyperoside, isoquercitrin, quercetin, quercitrin and rutin) content $\left(\mathrm{mg} \cdot 100 \mathrm{~g}^{-1}\right)$ in the flowers of the 26 studied species. Different lower case letters in a row indicate significant differences between species according to Tukey's posthoc test $(p<0.05)$. Data are means of three biological replicates. -, compound not detected. ${ }^{\S}$ Flowers sampled from cultivated plants.

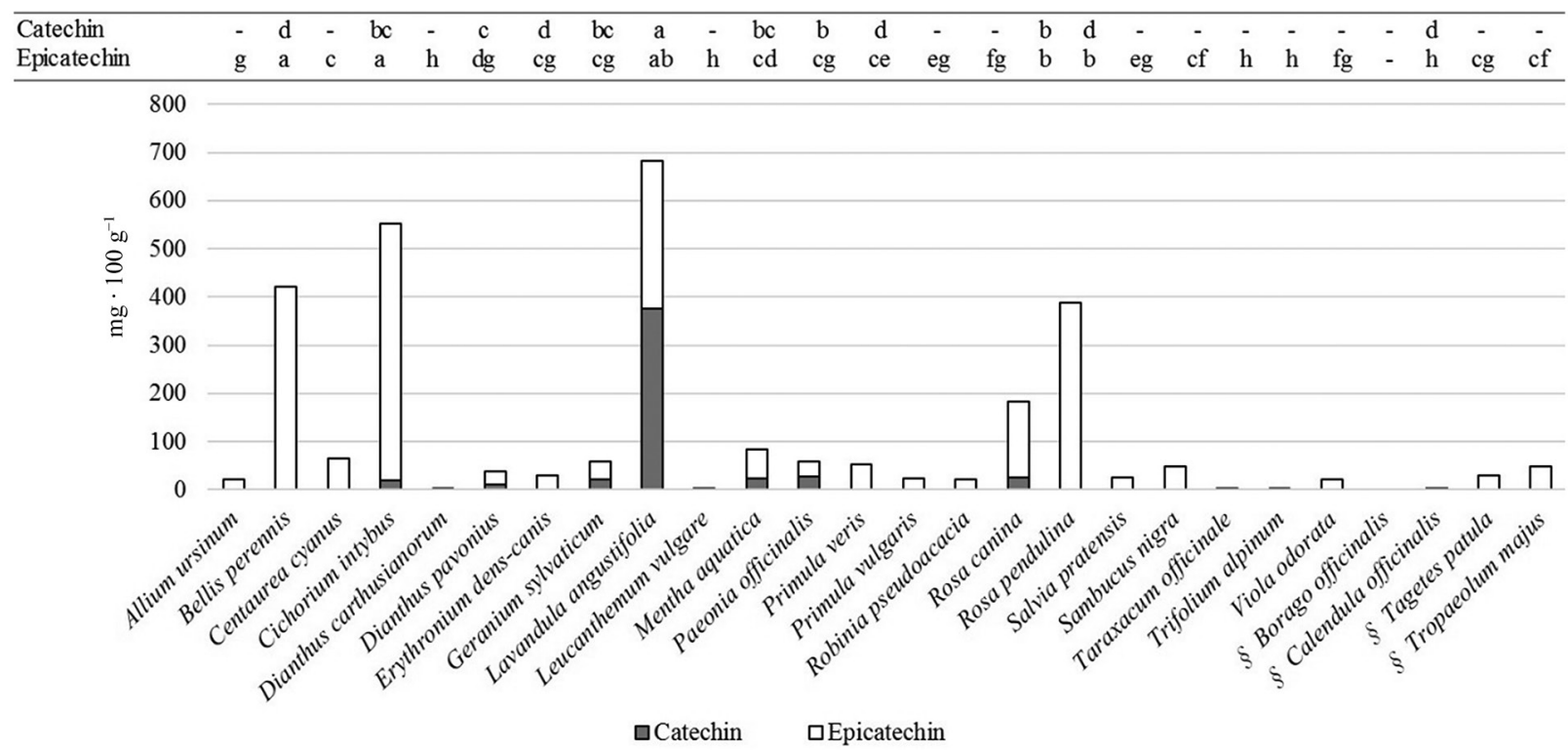

Figure A2. Flavanols (catechin and epicatechin) content $\left(\mathrm{mg} \cdot 100 \mathrm{~g}^{-1}\right)$ in the flowers of the 26 studied species. Different lower case letters in a row indicate significant differences between species according to Tukey's post-hoc test $(p<0.05)$. Data are means of three biological replicates. -, compound not detected. ${ }^{\S}$ Flowers sampled from cultivated plants. 


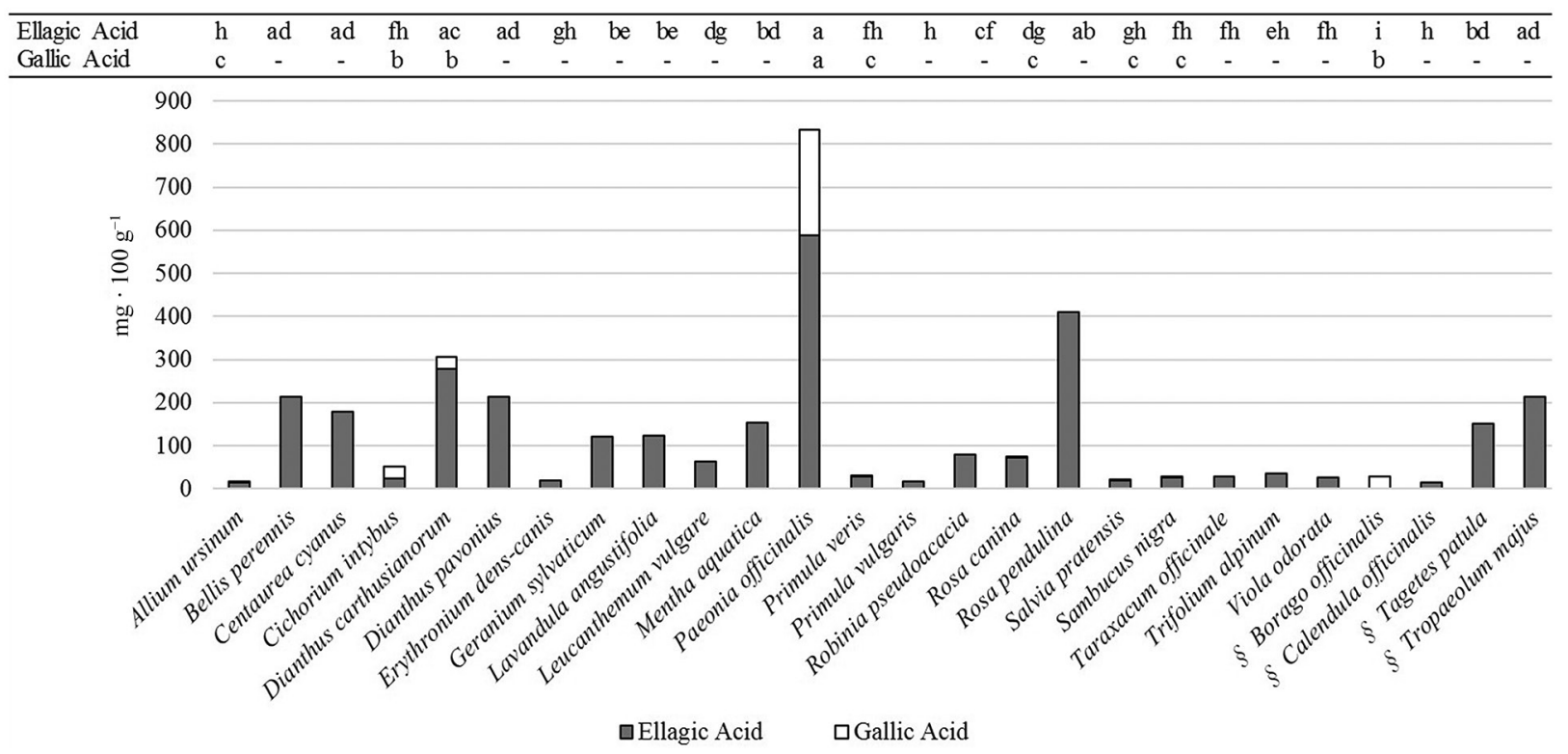

Figure A3. Benzoic acids (ellagic and gallic acid) content $\left(\mathrm{mg} \cdot 100 \mathrm{~g}^{-1}\right)$ in the flowers of the 26 studied species. Different lower case letters in a row indicate significant differences between species according to Tukey's post-hoc test $(p<0.05)$. Data are means of three biological replicates. -, compound not detected. ${ }^{\S}$ Flowers sampled from cultivated plants.

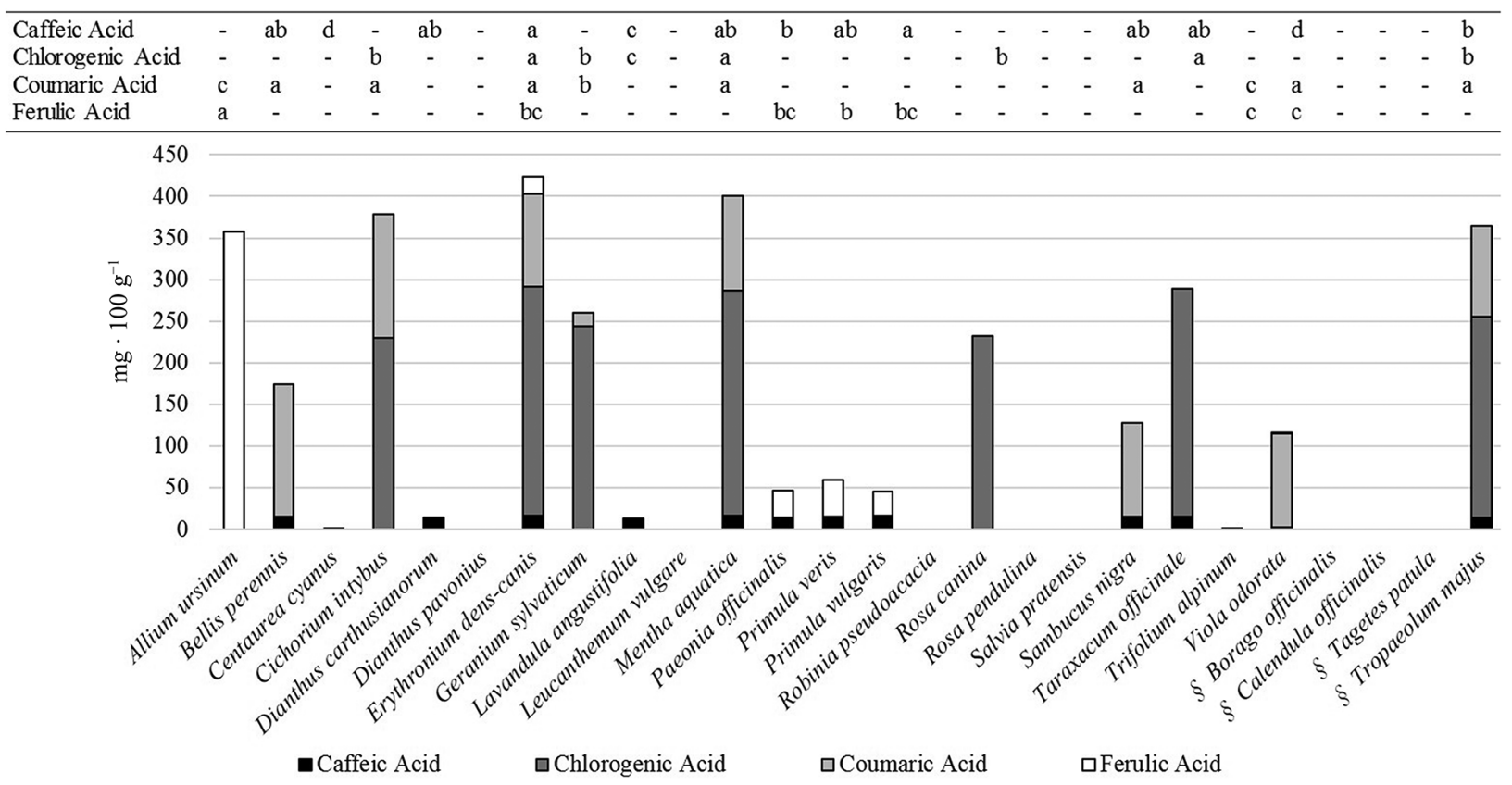

Figure A4. Cinnamic acids (caffeic, chlorogenic, coumaric and ferulic acid) content $\left(\mathrm{mg} \cdot 100 \mathrm{~g}^{-1}\right)$ in the flowers of the 26 studied species. Different lower case letters in a row indicate significant differences between species according to Tukey's post-hoc test $(p<0.05)$. Data are means of three biological replicates. -, compound not detected. ${ }^{\S}$ Flowers sampled from cultivated plants. 